\title{
Estimated Infiltration, Percolation, and Recharge Rates at the Rillito Creek Focused Recharge Investigation Site, Pima County, Arizona
}

\author{
By John P. Hoffmann, Kyle W. Blasch, Don R. Pool, Matthew A. Bailey, and James B. Callegary
}

\section{Abstract}

A large fraction of ground water stored in the alluvial aquifers in the Southwest is recharged by water that percolates through ephemeral stream-channel deposits. The amount of water currently recharging many of these aquifers is insufficient to meet current and future demands. Improving the understanding of streambed infiltration and the subsequent redistribution of water within the unsaturated zone is fundamental to quantifying and forming an accurate description of streambed recharge. In addition, improved estimates of recharge from ephemeralstream channels will reduce uncertainties in water-budget components used in current ground-water models.

This chapter presents a summary of findings related to a focused recharge investigation along Rillito Creek in Tucson, Arizona. A variety of approaches used to estimate infiltration, percolation, and recharge fluxes are presented that provide a wide range of temporal- and spatial-scale measurements of recharge beneath Rillito Creek. The approaches discussed include analyses of (1) cores and cuttings for hydraulic and textural properties, (2) environmental tracers from the water extracted from the cores and cuttings, (3) seepage measurements made during sustained streamflow, (4) heat as a tracer and numerical simulations of the movement of heat through the streambed sediments, (5) water-content variations, (6) water-level responses to streamflow in piezometers within the stream channel, and (7) gravity changes in response to recharge events. Hydraulic properties of the materials underlying Rillito Creek were used to estimate long-term potential recharge rates. Seepage measurements and analyses of temperature and water content were used to estimate infiltration rates, and environmental tracers were used to estimate percolation rates through the thick unsaturated zone. The presence or lack of tritium in the water was used to determine whether or not water in the unsaturated zone infiltrated within the past 40 years. Analysis of water-level and temporal-gravity data were used to estimate recharge volumes. Data presented in this chapter were collected from 1999 though 2002. Precipitation and streamflow during this period were less than the longterm average; however, two periods of significant streamflow resulted in recharge — one in the summer of 1999 and the other in the fall/winter of 2000.

Flux estimates of infiltration and recharge vary from less than 0.1 to 1.0 cubic meter per second per kilometer of streamflow. Recharge-flux estimates are larger than infiltration estimates. Larger recharge fluxes than infiltration fluxes are explained by the scale of measurements. Methods used to estimate recharge rates incorporate the largest volumetric and temporal scales and are likely to have fluxes from other nearby sources, such as unmeasured tributaries, whereas the methods used to estimate infiltration incorporate the smallest scales, reflecting infiltration rates at individual measurement sites.

\section{Introduction}

The city of Tucson and surrounding areas obtain most of their municipal, agricultural, and industrial water from ground water that is withdrawn from thick, alluvial-basin aquifers. The amount of water currently recharging the aquifers within the Tucson area is insufficient to meet current and future demands. Resultant ground-water deficits are manifested in water-level declines of more than $60 \mathrm{~m}$ since the middle of the 20th century. These declines are largest where ground-water withdrawals are greatest.

The alluvial aquifers are recharged by infiltration from irrigation and industrial returns and by seepage losses through stream channels. In the Tucson area, where the climate is semiarid, diffuse recharge through the basin sediments from precipitation is considered a negligible component of total recharge owing to low precipitation rates and high evapotranspiration (ET) rates (Scott and others, 2000). For instance, annual precipitation averages $31.5 \mathrm{~cm}$ on the valley floor, and annual potential ET ranges from 90 to $190 \mathrm{~cm}$ (Yitayew, 1990). Additionally, depth to ground water in the underlying alluvial basin can be tens of meters, providing opportunity for ample storage of infiltrated water. Because of these conditions, concentrated infiltration repeated over time, such as infiltration from irrigation and industrial returns, is necessary for recharge to occur. A large fraction of ground water stored in the allu- 
vial aquifer was recharged by water that percolated through ephemeral stream-channel deposits (Davidson, 1973; Hanson and Benedict, 1994).

Rillito Creek, located in the Upper Santa Cruz Basin in southern Arizona (fig. 1), is typical of a large, ephemeral stream in the Southwest. In many basins of the Southwest, such as in the Upper Santa Cruz Basin, streams originating at higher elevations coalesce downstream to form larger ephemeral streams. Streams originating near mountain fronts typically flow over thick, alluvial valleys, lose hydraulic connection with the underlying aquifer, and are ephemeral in their lower reaches. Underlying many of these ephemeral streams is a coarse-grained stream-channel deposit that overlies a basin-fill deposit. The coarse-grained stream-channel deposit typically has high permeability and infiltration rates (Anderson and others, 1992; Hanson and Benedict, 1994).

Although recharge from infiltration of streamflow is known to occur in ephemeral-stream channels in the Southwest, such as Rillito Creek, the processes that control the spatial distribution and volume of infiltration that recharges the underlying aquifers are poorly understood. The Rillito Creek focused recharge investigation site was selected as one of six sites to study recharge processes in the Southwest (see chapter C) as part of the U.S. Geological Survey (USGS) Ground-Water Resources Program and generally is representative of ephemeral washes within the Sonoran Desert. Improving the understanding of streambed infiltration and the subsequent redistribution of water within the unsaturated zone is fundamental to quantifying and forming an accurate description of streambed recharge. Improved estimates of recharge from ephemeral stream channels will reduce uncertainties in water-budget components used in current ground-water models. In addition, recharge augmentation has been proposed along several reaches of ephemeral streams in the Tucson area, including Rillito Creek, and understanding processes that control recharge is important to the construction of recharge facilities.

\section{Purpose and Scope}

The purpose of this chapter is to present a summary of findings related to a focused recharge investigation along Rillito Creek, Pima County, Arizona. One of the challenges of quantitatively studying recharge beneath ephemeral streams is the need to integrate measurements made over a wide range of spatial and temporal scales. No single method of measurement or analysis can resolve the complex physical processes that contribute to infiltration, percolation, and recharge beneath ephemeral streams; therefore, a variety of approaches are presented that provide a wide range of temporal- and spatial-scale measurements of recharge beneath Rillito Creek.

Six approaches were used to evaluate infiltration, percolation, and recharge to the aquifer beneath Rillito Creek.
Cores and cuttings were collected during the drilling of five boreholes. Laboratory measurements used to determine physical and hydraulic properties of these cored subsurface materials (Hoffmann and others, 2002) represent the smallest spatial scale in this investigation. The core-based data typically are on the order of several centimeters, but are scaled up to meters in this report. Water content extracted from the cores, and environmental tracers measured in these waters, represent a temporal scale that is a function of the thickness and hydraulic properties of the unsaturated zone: in general, these data represent a time scale of less than 2 years in this investigation. Seepage measurements made during sustained streamflow represent portions of a streamflow event and typically have time scales of a few hours to several days. Measurements of temperature and water content in vertical (one-dimensional) and two-dimensional profiles represent spatial scales that are typically less than $5 \mathrm{~m}$ and have temporal scales that vary from seconds to several days. Vertically nested piezometers were installed in the boreholes drilled in the stream channel to monitor water-level responses to streamflow. These measurements also represent a temporal scale that is a function of the thickness and hydraulic properties of the unsaturated zone and, in general, represents a time scale of weeks to several months in this investigation. Measurements of ground-water storage changes using temporal-gravity measurements have the largest spatial and temporal scales spanning several square kilometers and a period of record of several months to years. Data presented in this chapter were collected from 1999 through 2002.

\section{Previous Investigations}

Smith (1910) probably was the first investigator to examine recharge along Rillito Creek. He concluded there was a difference in infiltration rates between the flashy, silt-laden summer flows, and the steady, long-duration flows of the winter snowmelt runoff. This conclusion was based partly on seasonal well hydrographs and ground-water temperature data. Investigators to follow, such as Schwalen and Shaw (1957) and Matlock (1965), also concluded that winter streamflow was the most effective source of recharge to the Tucson Basin. Burkham (1970) developed an empirical formula to estimate infiltration along a $15-\mathrm{km}$ reach of Rillito Creek on the basis of streamflow losses between discharge measurement points. Davidson (1973) suggested that at least 90 percent of the amount of infiltrated water results in recharge. The remaining 10 percent is lost to ET. Although not necessarily specific to Rillito Creek, the work of Wallace and Lane (1978) related infiltration potential to stream-channel order. Wallace and Lane concluded that the greatest infiltration potential occurs in the large-order streams because these streams contain the greatest volume of alluvium. Hanson and Benedict (1994) summarized previous estimates of recharge and developed new estimates on the basis of work by previous investigators and numerical simulation. 


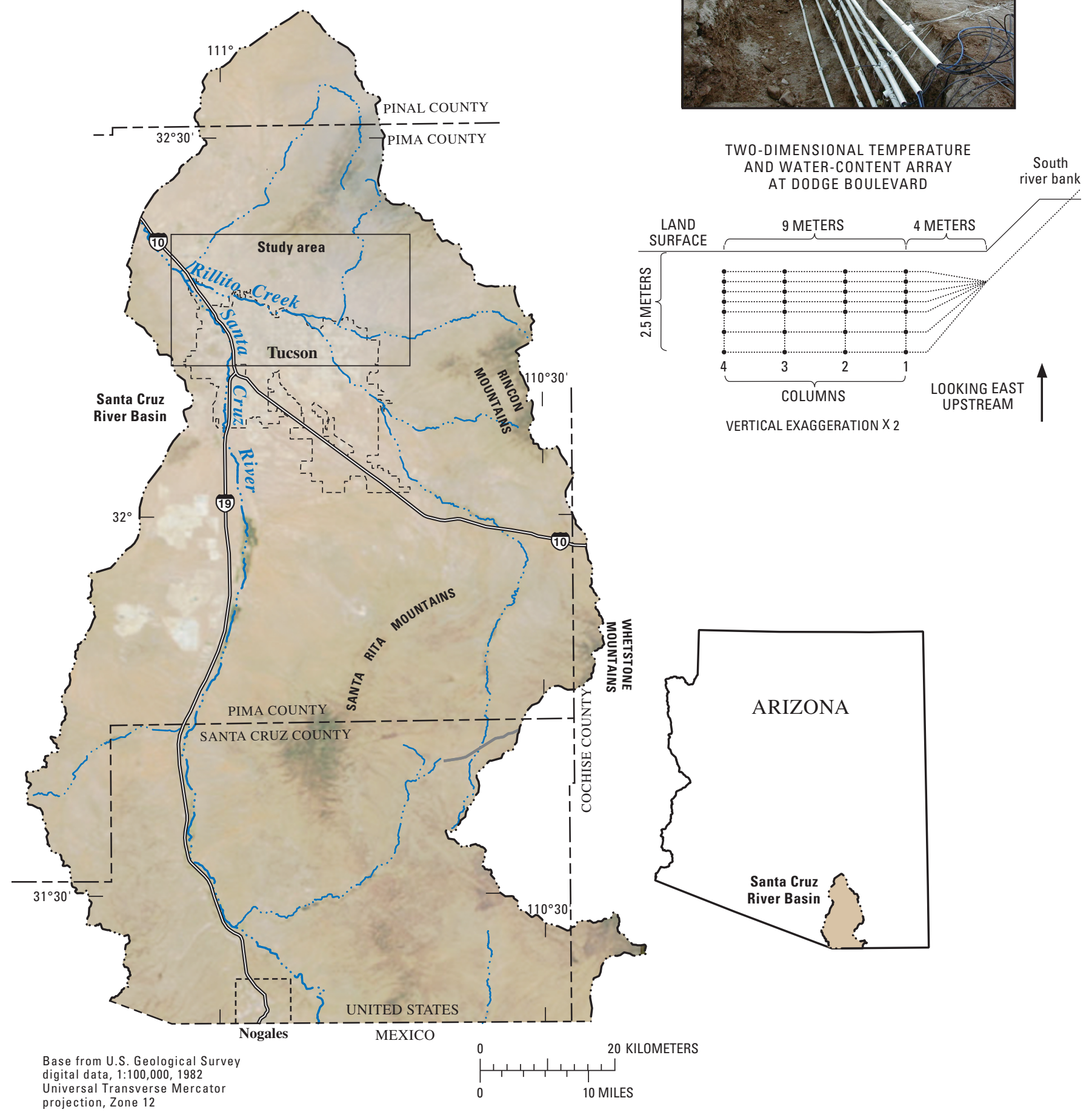

Figure 1. Location of study area, Pima County, Arizona. 


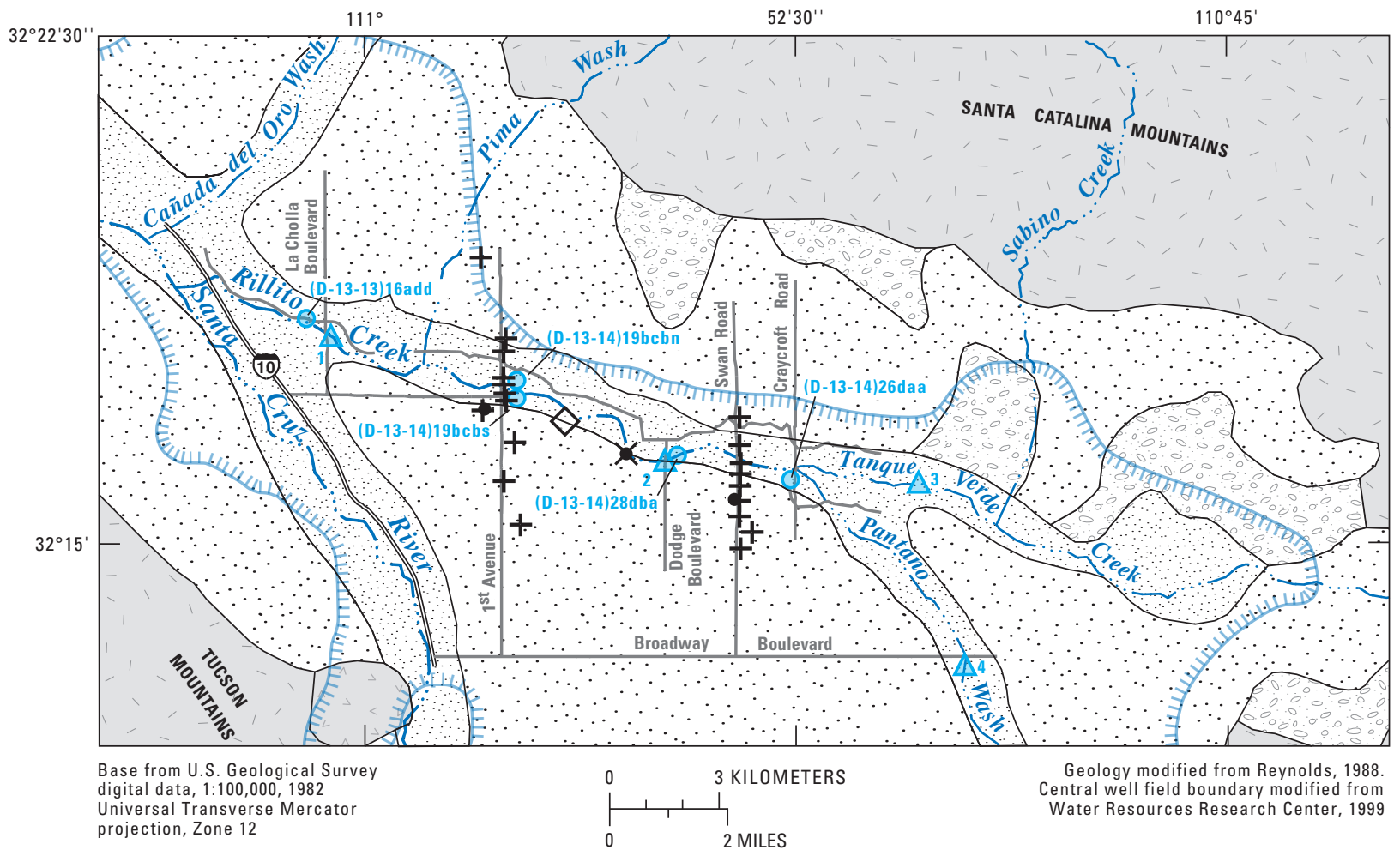

EXPLANATION

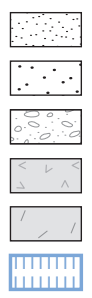

STREAM ALLUVIUM

QUATERNARY ALLUVIUM

TERTIARY AlLUVIUM

VOLCANIC ROCK

CRYSTALLINE ROCK

CENTRAL WELL FIELD
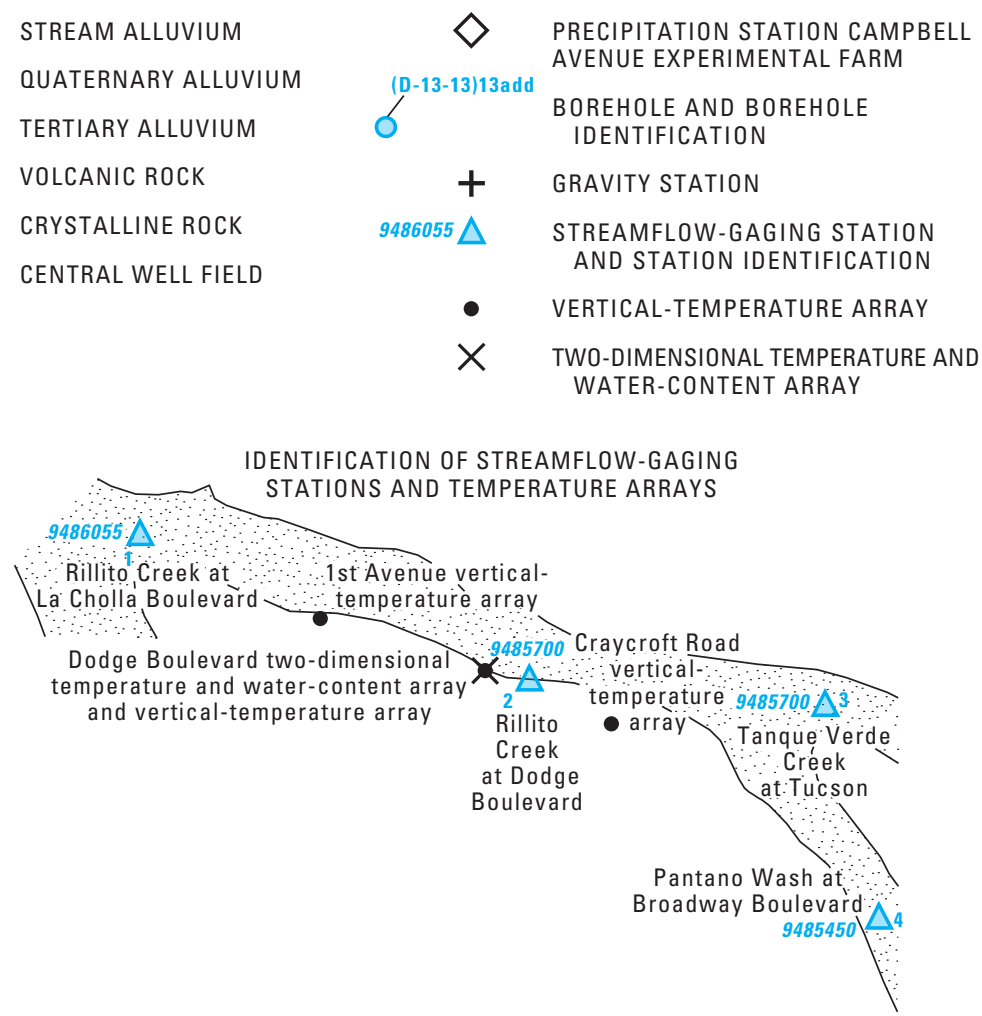

Figure 1.-Continued. 


\section{Hydrologic Setting}

The climate of the study area is semiarid; annual rainfall averages $315 \mathrm{~mm}$ on the valley floor (fig. 2). There are two distinct seasons that account for most of the total precipitation; one (generally from July through September) is characterized by large summer convection and the other (generally from November through February) is characterized by frontal storms (fig. 2). The mean temperatures in January and July are $10^{\circ} \mathrm{C}$ and $29.6^{\circ} \mathrm{C}$, respectively. To a lesser extent, there is a fall season of precipitation associated with tropical storms and climatic oscillations.

Rillito Creek is a tributary of the Santa Cruz River, which drains the Upper Santa Cruz Basin in southern Arizona. The Upper Santa Cruz Basin is in the Basin and Range Physiographic Province, which is characterized by block-faulted mountains separated by basins filled with alluvial sediments. The block-faulted mountains comprise Precambrian through Tertiary granitic, metamorphic, volcanic, and consolidated sedimentary rocks. The sediments that fill the basins are collectively termed alluvial basin-fill deposits and are composed of gravel, sand, silt, clay, and minor amounts of anhydrous sediments of Tertiary to Quaternary age. The basin-fill deposits generally are coarse grained along the basin margins and grade into finer-grained deposits and anhydrite deposits in the central parts of the basins. In the Upper Santa Cruz River Basin, thickness of the alluvium ranges from a thin veneer (a few meters) along the mountain fronts to as much as 3,400 m in the central parts of the basin (Davidson, 1973; Anderson, 1987, 1988; Hanson and Benedict, 1994).

Recent stream-channel deposits and basin-fill deposits underlie Rillito Creek. The recent stream-channel deposits, consisting of fine- to coarse-grained alluvium, are about $10 \mathrm{~m}$ thick and are detritus from the surrounding mountain ranges. The basin-fill deposits, which underlie the stream-channel deposits, are regionally extensive sedimentary units that form the regional aquifer system. Previous investigators have divided the basinfill deposits into upper and lower basin-fill units on the basis of their general hydrogeologic characteristics (Pool, 1986; Hanson and Benedict, 1994). The upper basin-fill unit can be as much as $300 \mathrm{~m}$ thick. It consists mostly of unconsolidated to semiconsolidated gravel, sands, and clayey silt and is correlated to the upper Tinaja beds and the Fort Lowell Formation described by Anderson $(1987,1988)$. The lower basin-fill unit is a few thousand meters thick and consists of conglomerates, gravels, sands, silts, anhydritic clayey silts, and mudstones (Anderson, 1988). The lower basin-fill unit is represented by the Pantano Formation and the lower and middle Tinaja beds described by Anderson (1987, 1988).

Stream-channel infiltration is the predominant mechanism of recharge to the regional aquifer in the basin-fill deposits and, combined with contributions from other sources of recharge for the area, is less than the amount of water withdrawn to support the growing metropolitan population. As a result, water-level declines and related land subsidence have occurred in some areas. Depth to ground water immediately beneath Rillito Creek ranges from less than $6 \mathrm{~m}$ in the upper reach (near the mountain front) to $45 \mathrm{~m}$ near the Santa Cruz River (Hoffmann and others, 2002). Flow of ground water generally is northwestward; water-table elevations range from about $760 \mathrm{~m}$ in the southeast to $640 \mathrm{~m}$ in the northwest (Tucson Water, 2000). Ground water flows southwestward near the upper reach of Rillito Creek toward the major pumping center within the city of Tucson.

Rillito Creek has a drainage area of $2,256 \mathrm{~km}^{2}$. It is ephemeral and most flows occur during the summer monsoon (July-September) and winter frontal storms (DecemberMarch; fig. 2). Characteristic monsoon streamflows result from localized short-duration convective storms, whereas winter streamflows are produced by longer-duration frontal storms and accumulated snowmelt. To a lesser extent, there also is a fall season in which tropical storms and climatic oscillations often result in streamflow.

The creek has two major tributaries, Tanque Verde Creek and Pantano Wash; Rillito Creek begins at the confluence of these two tributaries. Tanque Verde Creek drains a $702 \mathrm{~km}^{2}$ area from the Santa Catalina and Rincon Mountains; Pantano Wash drains a $1,554 \mathrm{~km}^{2}$ area between the Rincon, Santa Rita, and Whetstone Mountains. Several small washes divert runoff from the northeastern suburbs of Tucson into Rillito Creek. Rainfall runoff and snowmelt runoff from the Santa Catalina and Rincon Mountains contribute most of the flow to Rillito Creek. The creek flows westward to the Santa Cruz River from an elevation of $762 \mathrm{~m}$ at the confluence of Tanque Verde Creek and Pantano Wash to $657 \mathrm{~m}$ at its confluence with the Santa Cruz River. The creek is about $100 \mathrm{~m}$ wide and the channel slopes toward the Santa Cruz River at approximately $5.2 \mathrm{~m} / \mathrm{km}$ with little variation in the slope. Flows in Rillito Creek typically are less than 28 $\mathrm{m}^{3} / \mathrm{s}$; the maximum recorded discharge was $680 \mathrm{~m}^{3} / \mathrm{s}$ during the 1993 El Niño season (Tadayon and others, 2000). On average, Rillito Creek flows about 36 days per year at the streamflowgaging station Rillito Creek at Dodge Boulevard (09485700). The average annual flow is approximately $33.3 \times 10^{6} \mathrm{~m}^{3}$; about 44 percent of the flow occurs from the summer monsoonal storms, whereas about 56 percent of the flow occurs from the winter frontal storms.

The amount of water flowing in Rillito Creek, and therefore the amount available for recharge, is primarily related to precipitation frequency, distribution, and intensity, as well as to basin/channel runoff characteristics. The temporal distribution of flow in ephemeral streams is highly variable with observed decadal oscillations (Webb and Betancourt, 1992; Don Pool, Hydrologist, U.S. Geological Survey, written commun., 2003). Because of this, it is particularly difficult to estimate or predict recharge rates for ephemeral-stream channels on the basis of limited temporal observations. During the period of investigation there were two significant streamflow periods (fig. 3); one occurred in the summer of 1999 and the other in the fall of 2000 (mostly after September 30, or during water year 2001). Annual streamflow in Rillito Creek for the period of study was somewhat less frequent and smaller in volume than the long-term average (table 1). Prior to this study, a significant streamflow period occurred in the winter 

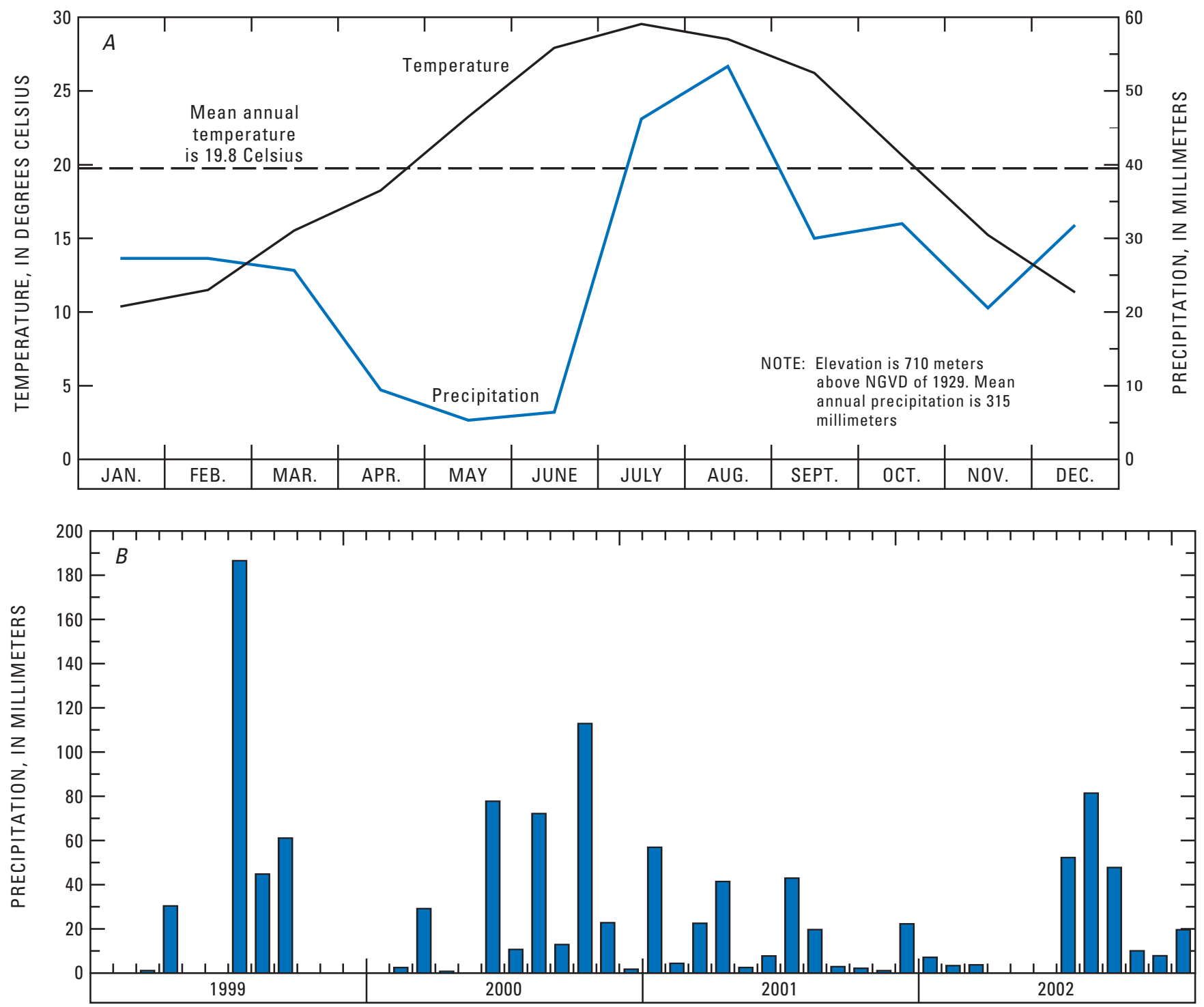

Figure 2. A, Monthly average temperature and precipitation, 1972-2002, at National Weather Service Station Campell Avenue Experimental Farm near Rillito Creek, Pima County, Arizona; B, monthly precipitation near Rillito Creek during period of study, $1999-2002$.

and spring of 1998 (water year 1998) that was associated with El Niño precipitation and snowmelt. From February through April 1998, a total of $28.7 \times 10^{6} \mathrm{~m}^{3}$ flowed past the streamflowgaging station at Dodge Boulevard.

\section{Infiltration, Percolation, and Recharge Rates}

\section{Physical and Hydraulic Properties of Stream- Channel and Basin-Fill Deposits}

In March and April 1999, five boreholes were drilled at four sites in the active channel of Rillito Creek (fig. 1) to determine the physical and hydraulic properties of the stream-channel and basin-fill sediments down to about 10 $\mathrm{m}$ below the water table (Hoffmann and others, 2002). Each borehole was drilled using the ODEX air-hammer method, which is also known as the under-reamer method (Driscoll, 1986; Hammermeister and others, 1986). The ODEX method was used because it does not use fluids, thereby minimizing disturbance of the subsurface materials. At each hole, cuttings were collected about every $0.3 \mathrm{~m}$. Fifty-one cores also were collected from these boreholes at 2- to 6-m intervals. The cores and cuttings were analyzed for physical properties, such as particle-size distribution, bulk density, particle density, porosity, volumetric water content, and percent saturation, and for hydraulic properties, such as saturated and unsaturated hydraulic conductivity, matric potential, and water-retention fitting terms. The detailed findings of these analyses are 
described in Hoffmann and others (2002). This section of the chapter focuses on the hydraulic properties of the sediments and their role in infiltration rates, velocity of the wetting front, and potential recharge.

In order for ephemeral streamflow within Rillito Creek to recharge the underlying aquifer, the water must first infiltrate into the stream-channel deposits and percolate downward through the underlying deposits. The ability of water to infiltrate and percolate through these deposits is primarily a function of stream discharge and hydraulic properties of the deposits. One-dimensional steady-state vertical flow through a homogeneous, isotropic medium can be described by a form of Darcy's Law as:

$$
q=-K(\theta)(\partial \psi / \partial z+1),
$$

where

$$
\begin{aligned}
q & \text { is the flux }[L / T], \\
\theta & \text { is the volumetric water content, } \\
K(\theta) & \text { is the hydraulic conductivity }[L / T] \text { as a } \\
& \text { function of the volumetric water content, } \\
\psi & \text { is the pressure head of the water phase }[L], \\
& \text { and } \\
z & \text { is the vertical dimension }[L] .
\end{aligned}
$$

Determination of the rate of flow requires knowledge of the hydraulic conductivity and saturation of the porous media, and the head gradient. Water continues to move within the unsaturated zone after it has infiltrated across the ground surface.

This subsurface redistribution is described by the unsaturatedflow equation:

\begin{tabular}{|c|c|c|c|c|}
\hline $\begin{array}{l}\text { Water } \\
\text { year }^{1}\end{array}$ & $\begin{array}{c}\text { Total } \\
\text { annual } \\
\text { streamflow, } \\
\text { in cubic } \\
\text { meters }\end{array}$ & $\begin{array}{c}\text { Annual } \\
\text { flow as a } \\
\text { percentage } \\
\text { of long-term } \\
\text { annual } \\
\text { streamflow }\end{array}$ & $\begin{array}{l}\text { Percentage } \\
\text { of annual } \\
\text { stream- } \\
\text { flow that } \\
\text { occurred in } \\
\text { summer }\end{array}$ & $\begin{array}{l}\text { Percentage } \\
\text { of annual } \\
\text { stream- } \\
\text { flow that } \\
\text { occurred in } \\
\text { winter }\end{array}$ \\
\hline 1999 & $11 \times 10^{6}$ & 33 & 98 & 2 \\
\hline 2000 & $3.5 \times 10^{6}$ & 10.5 & 100 & 0 \\
\hline 2001 & $19.6 \times 10^{6}$ & 59 & 5 & 95 \\
\hline 2002 & $2 \times 10^{6}$ & 6 & 99 & 1 \\
\hline
\end{tabular}

$$
\partial \theta / \partial t=\nabla q,
$$

with the flux, $q$, as defined above. Because redistribution is inherently transient and multidimensional, fewer simplifying
Table 1. Annual streamflow measured at Rillito Creek at Dodge Boulevard (streamflow-gaging station 09485700), Pima County, Arizona, during period of study.

${ }^{1}$ Water year extends from October 1 through September 30 and is designated by the calendar year in which it ends.

assumptions can be applied in the analysis of redistribution than can be applied to infiltration. To fully characterize subsurface redistribution, measurements of both water flux and changes in subsurface water storage must be made repeatedly throughout the unsaturated zone.

As shown in the section titled "Temperature and Water Content," vertical infiltration rates at the onset of infiltration were as high as $22 \mathrm{~mm} / \mathrm{s}$ because of high hydraulic permeability, low antecedent water content, and resulting large capillary gradients. Two-dimensional flow is also evident, and lateral velocities were about the same as vertical velocities. Shortly after the onset of infiltration, however, the near-surface stream-channel deposits are saturated, and large capillary gradients decline. Flow of water becomes predominantly vertical, as gravity is the dominant process controlling the

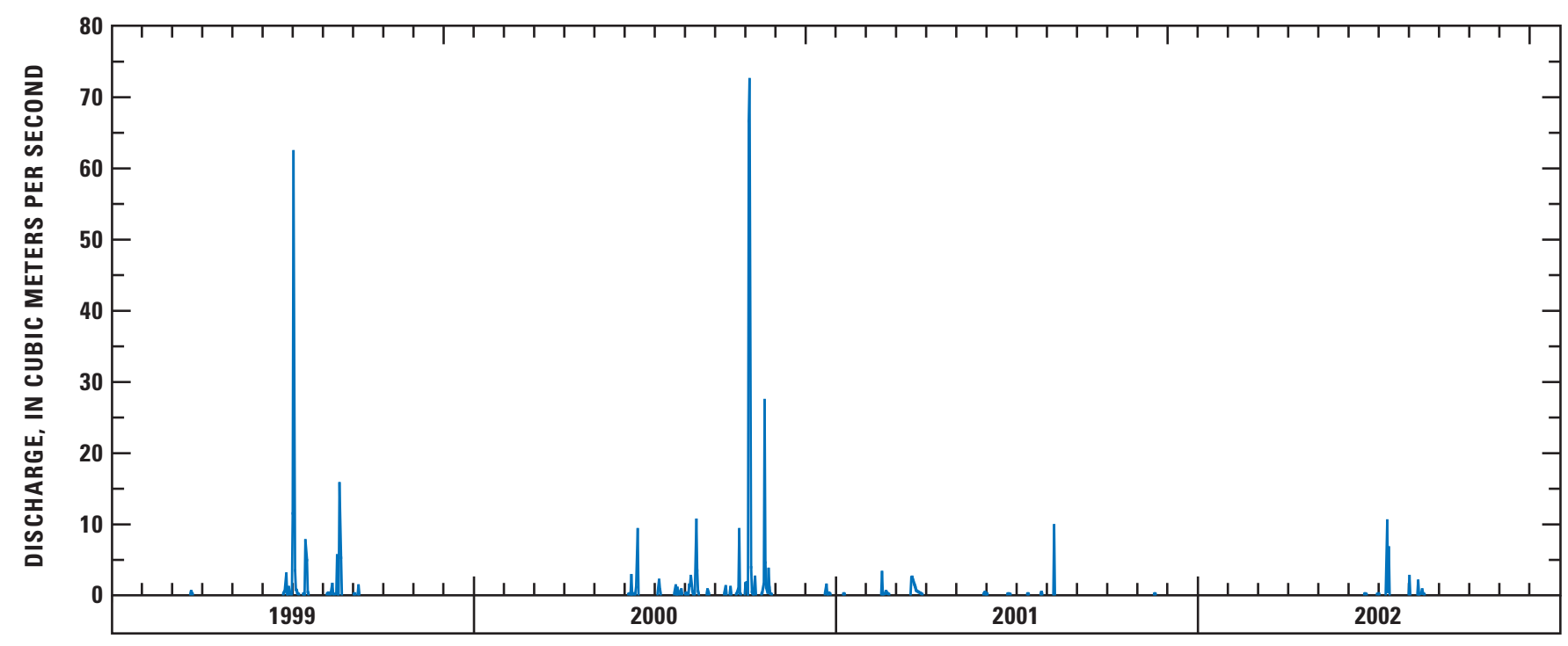

Figure 3. Mean discharge at Rillito Creek at Dodge Boulevard (streamflow-gaging station 09485700), 1999-2002, Pima County, Arizona. 
direction of flow. From Darcy's Law, the flow rate through the sediments under saturated conditions is equal to the product of the hydraulic conductivity and the hydraulic gradient. If both hydraulic conductivity and gradient are known, then the flow rate can be calculated. This method of flow-rate estimation can be used for saturated and unsaturated conditions. Assuming properties of the pore water are constant, saturated hydraulic conductivity $\left(K_{s a t}\right)$ is a constant and is related to the texture and structure of the sediment. Unsaturated hydraulic conductivity is not a constant as it decreases rapidly as water content decreases. As surface flow proceeds, the infiltrated water moves farther below the surface of the streambed, capillary forces become less significant, and the hydraulic gradient approaches unity. If a unit gradient is assumed, the rate of infiltration becomes equivalent to the saturated hydraulic conductivity of the channel deposits.

On the basis of findings from the cuttings and cores, the stream-channel deposits beneath Rillito Creek are coarse grained, typically consisting of more than 95 percent gravel and sand. The underlying basin-fill deposits also are sandy gravels or gravelly sands, but typically contain more silt and clay than the stream-channel deposits.

Saturated vertical hydraulic conductivity of the deposits positively correlates with grain size (fig. 4). Values for the stream-channel deposits range from 0.3 to $2.5 \mathrm{~m} / \mathrm{d}$, whereas values for the basin-fill deposits tend to be less than about $0.6 \mathrm{~m} / \mathrm{d}$ and in places are as low as $0.012 \mathrm{~m} / \mathrm{d}$. For heterogeneous media, such as the deposits beneath Rillito Creek, the equivalent vertical hydraulic conductivity is calculated as the harmonic mean of the $K_{s a t}$ for each layer within the deposits and is always less than the arithmetic mean (Freeze and Cherry, 1979). Although differing at each borehole, the overall average equivalent hydraulic conductivity of the streamchannel deposits is $1.2 \mathrm{~m} / \mathrm{d}$; the overall average equivalent hydraulic conductivity of the basin-fill deposits is $0.19 \mathrm{~m} / \mathrm{d}$; and the equivalent hydraulic conductivity of the combined sediments (stream-channel and basin-fill deposits) is $0.23 \mathrm{~m} / \mathrm{d}$. The calculated average vertical hydraulic conductivity for the basin-fill sediments reported by Hoffmann and others (2002) includes values associated with a fine-grained unit found in a lower reach of Rillito Creek near the Santa Cruz River. These values typically are as low as $0.012 \mathrm{~m} / \mathrm{d}$ and may not be representative of the hydraulic conductivity in upstream reaches. Excluding the hydraulic-conductivity values for the basin-fill sediments in the lower reaches where the fine-grained unit was present, the average vertical hydraulic conductivity of the study area is $0.3 \mathrm{~m} / \mathrm{d}$. Assuming a unit gradient, equivalent vertical hydraulic conductivity values are equivalent to the rate of infiltration and provide an estimate of potential recharge rates under saturated conditions.

Saturated conditions will exist only after sustained periods of streamflow infiltration at a rate that enables water to fully saturate the underlying sediments from the streambed to the aquifer. Once a saturated hydraulic connection is achieved between the stream and underlying aquifer, the system behaves as though the stream were perennial. Unsaturated hydraulic-

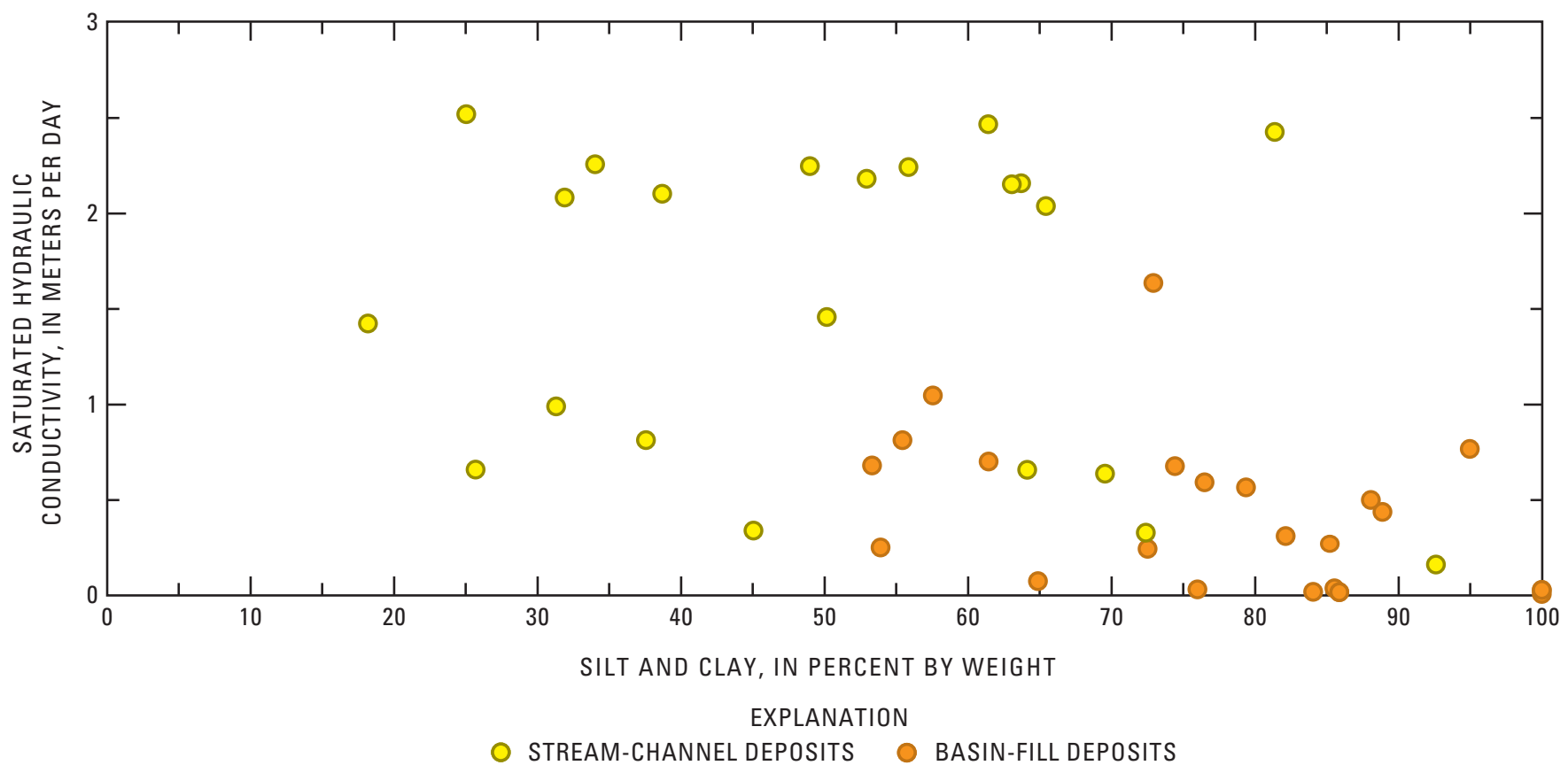

Figure 4. Relation of saturated hydraulic conductivity to sand, silt, and clay content for cores collected from boreholes drilled along Rillito Creek, Pima County, Arizona. 
conductivity values need to be considered when estimating potential recharge rates for conditions prior to full saturation. Unsaturated hydraulic conductivity of the deposits beneath Rillito Creek varies by several orders of magnitude as a function of water content. For water-content conditions at the time of core collection, the unsaturated hydraulic conductivity was generally two or more orders of magnitude less than the saturated hydraulic conductivity (Hoffmann and others, 2002).

Antecedent pore water underlying Rillito Creek derives from streamflow infiltration and subsequent percolation. In this study, cores were collected in late March 1999; therefore, antecedent pore water was derived from streamflows prior to March 1999. Several flow events prior to 1999 could have been sources of the antecedent water. On the basis of streamflow records at the streamflow-gaging station at Dodge Boulevard, the most recent flow prior to core collection occurred in November 1998 and lasted for 2 days (average streamflow was less than $0.82 \mathrm{~m}^{3} / \mathrm{s}$ ). The last recorded flow prior to November 1998 occurred in the summer of 1998 and lasted for about 1 day. The most voluminous and long-lasting flow within a few years of the core collection was the sustained flow from February to April 1998, which was related to the 1998 El Niño precipitation.

Volumetric water content in the unsaturated zone ranged from 0.02 to 0.46 at the time of core collection (fig. 5). Variability in water content primarily is controlled by differences in sediment texture and is positively correlated with the percentage of fine-grained material (fig. 5). The stream-channel deposits averaged 17.8 percent water content and 57.6 percent saturation; the basin-fill deposits averaged 24 percent water content and 69.3 percent saturation. Integrating the water content over the thickness of the unsaturated zone, cumulatively, the unsaturated sediments beneath Rillito Creek contained 0.5 to $12.2 \mathrm{~m}$ of water. The smallest amount of water was in the upstream area at the borehole ((D-13-14)26daa) near Craycroft Road where the unsaturated zone was about 3 m thick; the largest amount of water was in the downstream area at the borehole ((D-12-14)26add) near La Cholla Boulevard where a 12-m thick fine-grained unit lies above the water table. The sites probably most representative of the unsaturated zone beneath Rillito Creek are in the middle reaches where the unsaturated zone was 30 to $40 \mathrm{~m}$ thick and had $6.1 \mathrm{~m}$ of water (boreholes (D-1314)19bcbn, (D-13-14)19bcbs, and (D-13-14)28dba). The large amount of water stored in the unsaturated zone indicates that much of this water probably originated from the sustained flows prior to the summer of 1998 , that the stored water is likely to be from several different streamflow and infiltration events, and that the sediments beneath Rillito Creek drain slowly.

\section{Environmental Tracers}

Environmental tracers of tritium $\left({ }^{3} \mathrm{H}\right)$, oxygen-18 $\left({ }^{18} \mathrm{O}\right)$, deuterium $\left({ }^{2} \mathrm{H}\right.$ or $\left.\mathrm{D}\right)$, and chloride from the pore waters in the unsaturated and saturated zones were analyzed to evaluate spatial variations in infiltration and recharge patterns along Rillito Creek. Tritium is a naturally occurring radioactive isotope of hydrogen with a half life of 12.43 years. Large concentrations of tritium were introduced into the atmosphere beginning in 1952 as a result of the atmospheric testing of nuclear

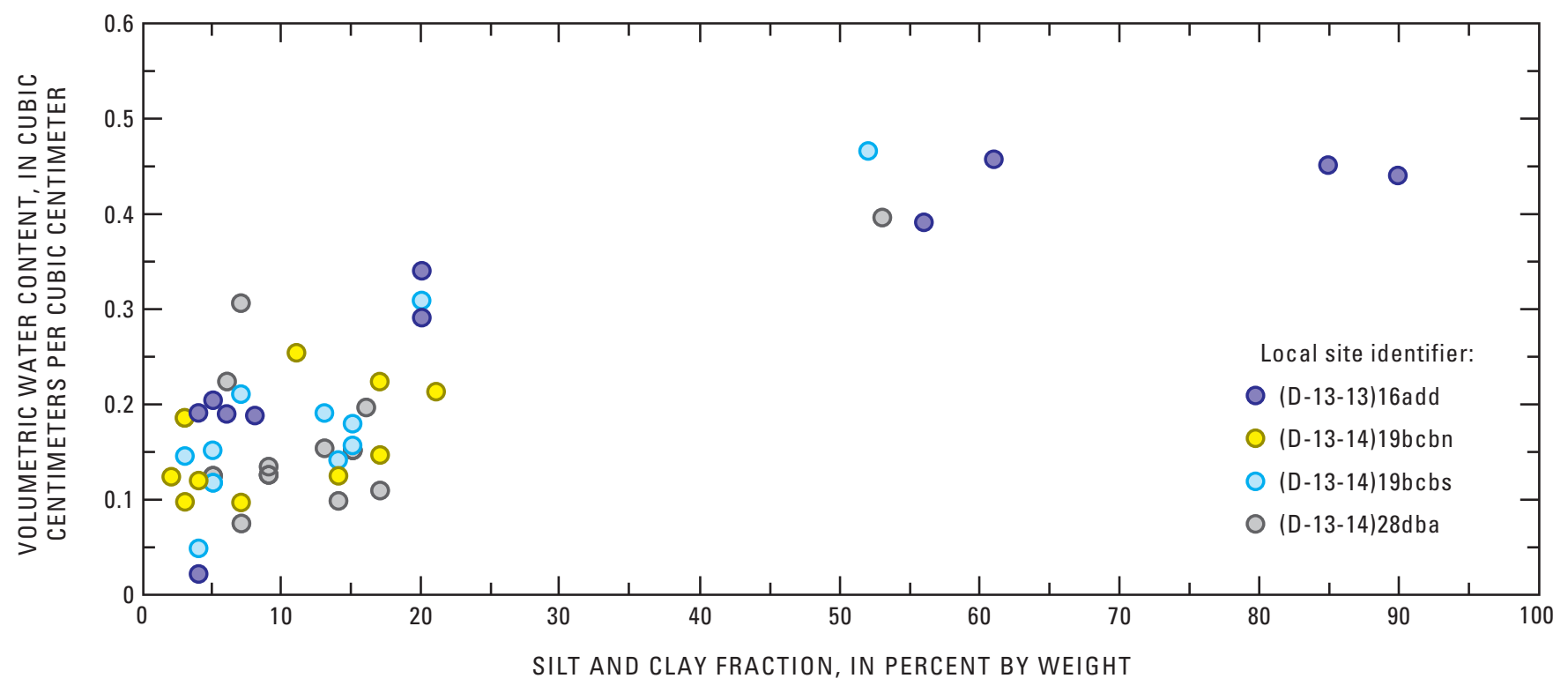

Figure 5. Relation of volumetric water content to sand, silt, and clay content for cores collected from boreholes drilled along Rillito Creek, Pima County, Arizona. 
weapons. The input of tritium into the atmosphere related to nuclear weapon testing peaked at nearly 6,000 tritium units (TU) in 1963-64 prior to a ban on the tests. Atmospheric tritium concentrations returned to natural conditions by 1992 (Dr. Chris Eastoe, geochemist, University of Arizona, written commun., 2003), and the concentration of tritium in precipitation today is about 5 to $7 \mathrm{TU}$. Tritium concentrations are often used for dating ground water and to detect events, such as the 1963-64 peak. In this study, tritium was measured in water vacuum extracted from cores and analyzed by liquid scintillation with electrolytic enrichment (Thatcher and others, 1977) at the USGS laboratory in Menlo Park, California. Tritium was detected in pore water extracted from each core sample and ranged in concentration from 2 to $11 \mathrm{TU}$ (fig. 6). The precision of individual measurements was $\pm 0.3 \mathrm{TU}$. For the purposes of this study, waters having tritium concentrations in this range are interpreted as having infiltrated within the past 40 years. Tritium concentrations within a given profile could not be used to identify an event marker, such as the 1963 peak.

Given the presence of tritium in the unsaturated zone, the locally high vertical hydraulic conductivity values of more than $1 \mathrm{~m} / \mathrm{d}$ in the stream-channel deposits, and depths to the water table of generally less than $40 \mathrm{~m}$, it is likely that most of the pore water extracted from the cores was derived from runoff events during the few years prior to 1999.

Assuming negligible mixing of infiltrated waters, variations in isotopic signatures and chloride concentrations can be used to identify individual runoff and infiltration events. These unique signatures remain intact during infiltration and allow direct identification of runoff events as the infiltrated water migrates through the unsaturated profile. Sampling through the unsaturated zone at a point in time provides a snapshot of the isotopic and chemical signatures throughout the profile. This snapshot represents the composition of the water that infiltrated into the sediment over a period of time- - the deepest water representing the beginning of the period. The downward rate of water movement at a particular site is calculated using the time elapsed between the runoff event and depth of infiltration of the water in the profile.

Oxygen and hydrogen isotopic compositions were determined for water extracted from cores by azeotropic distillation (Revesz and Woods, 1990) with toluene at the USGS laboratory in Reston, Virginia, using analytical methods described by Epstein and Mayeda (1953). Isotopic variations in water are expressed as a per mil ratio ( $\delta$ value), which is a ratio of ${ }^{18} \mathrm{O} /{ }^{16} \mathrm{O}$ and $\mathrm{D} /{ }^{1} \mathrm{H}$ in a sample relative to the ratio in an ocean water standard (Clark and Fritz, 1997). The delta symbol in this report is followed by the chemical symbol for the heavier isotope measured during isotopic analysis. Isotopic values are described as lighter or heavier in relation to each other. Lighter isotopic values are smaller or more negative per mil values, and heavier isotopic values are larger or more positive per mil values.

The source of precipitation is evaporation of seawater; therefore, the $\delta^{18} \mathrm{O}$ and $\delta \mathrm{D}$ composition of precipitation is linearly correlated, which is known as the meteoric water line

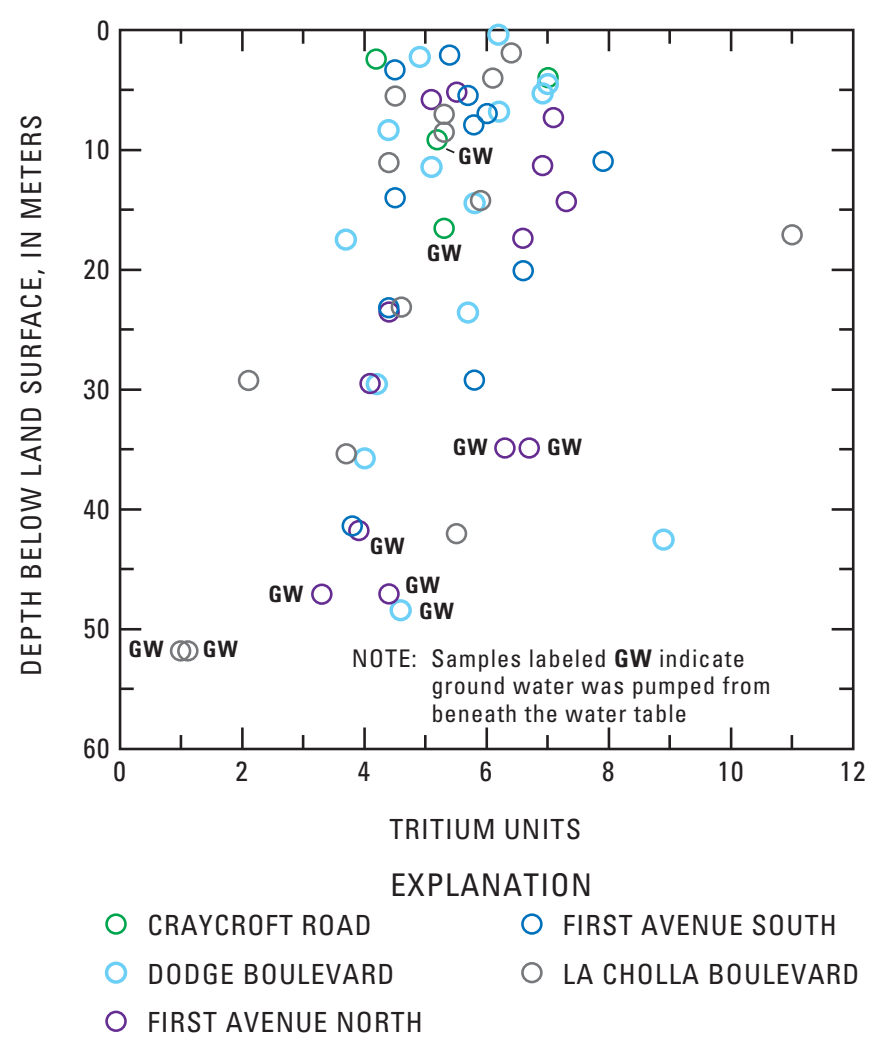

Figure 6. Profile of tritium content in water collected from boreholes drilled along Rillito Creek, Pima County, Arizona.

(MWL; Craig, 1961). Values of $\delta^{18} \mathrm{O}$ and $\delta \mathrm{D}$ in precipitation vary from event to event and also seasonally. Many variables influence the isotopic signature of a precipitation event, including the origin, travel path, and duration of the storm, and the elevation and temperature of condensation prior to rainfall. In general, however, variations in isotopic signature are predominately temperature dependent. The cool, high-altitude precipitation events produce water having lighter isotopic ratios than water from the warm precipitation events. In addition, evaporation will result in $\delta^{18} \mathrm{O}-\delta \mathrm{D}$ data for the remaining water that plot to the right of the MWL. A more detailed discussion on variations of isotopic ratios can be found in Clark and Fritz (1997).

Values of $\delta^{18} \mathrm{O}$ and $\delta \mathrm{D}$ in waters extracted from the unsaturated zone range from about -12 to -6 per mil, and -80 to -37 per mil, respectively (fig. 7). Data for many of the samples indicate the effect of evaporation (fig. 7). Isotopic compositions from the Dodge Boulevard site generally indicate the greatest amount of evaporation, and isotopic data from a sample collected at First Avenue North from a depth of less than $1 \mathrm{~m}$ indicated the greatest amount of evaporation for any sample (fig. 7). Variations in isotopic compositions of water from the unsaturated zone beneath Rillito Creek are, therefore, attributed to both changes in the isotopic signatures of the source water and to evaporation. Those samples that lack an evaporative signal indicate that percolating waters were not exposed to significant evaporation prior to infiltration. 
Several trends were evident in the isotopic ratios of Rillito Creek pore water. One trend is related to the location in the stream reach where the samples were collected. The waterweighted mean isotopic signature of the pore water in the unsaturated zone generally becomes lighter in the downstream direction (fig. 8). The water weighted mean uses the water content of the core as a weight that is multiplied by the isotopic ratio

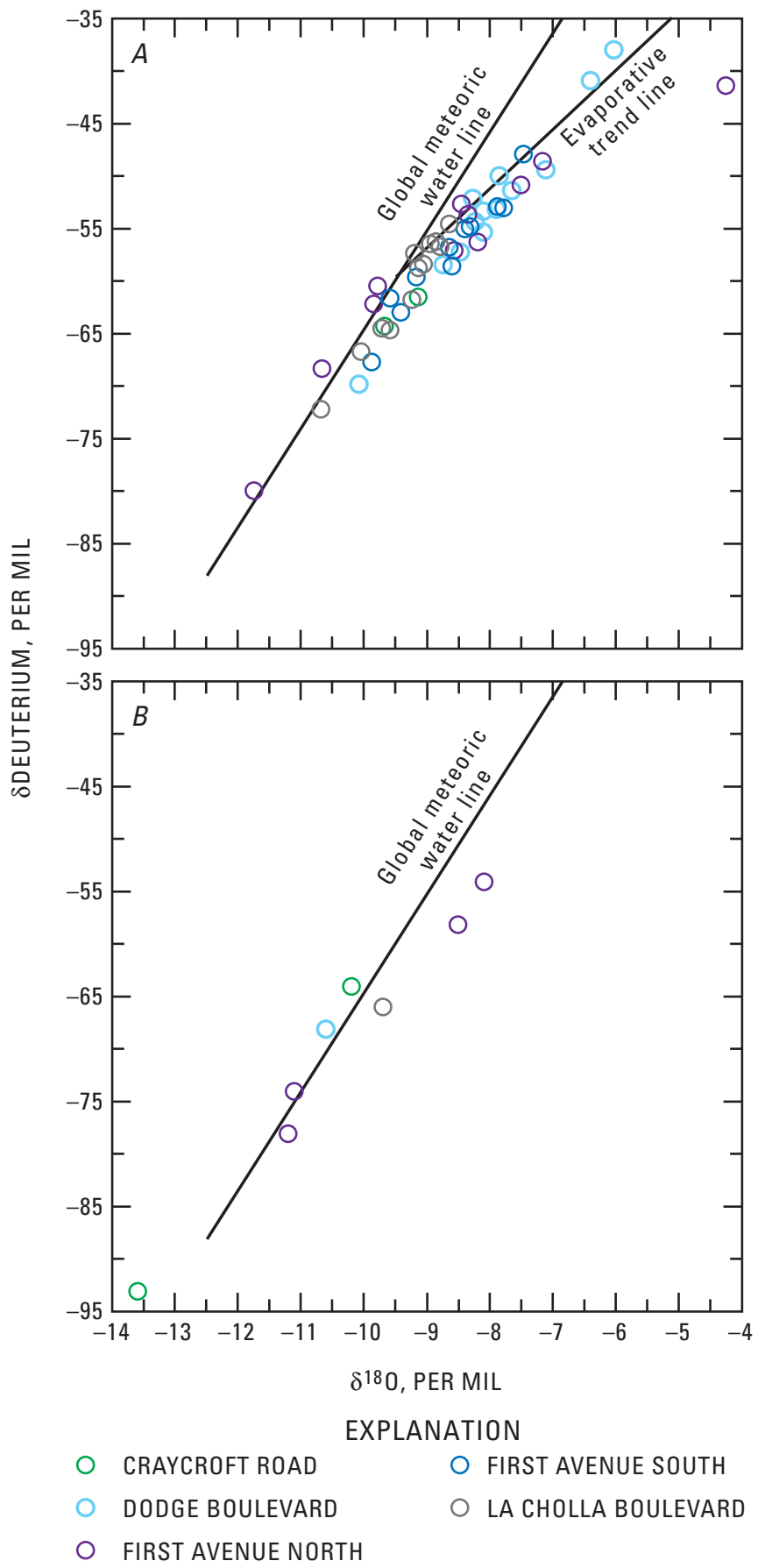

Figure 7. Stable isotope data of pore water collected from cores collected from boreholes drilled along Rillito Creek, Pima County, Arizona. $A$, unsaturated zone; $B$, below the water table. of the extracted water. Pore water in the borehole near Dodge Boulevard ((D-13-14)28dba) had $\delta^{18} \mathrm{O}$ and $\delta \mathrm{D}$ values of -8.0 of -55.0 per mil, respectively, whereas pore water downstream in the borehole near LaCholla ((D-13-13)16add) had $\delta^{18} \mathrm{O}$ and $\delta \mathrm{D}$ values of -9.5 and -64.0 per mil, respectively. At the intermediate boreholes near First Avenue ((D-13-14)bcbn and (D-1314)19bcbs), $\delta^{18} \mathrm{O}$ and $\delta \mathrm{D}$ values were -8.8 of -60.3 per mil, respectively. These variations are larger than the analytical precision (2-sigma values of 0.2 and 2 for $\delta^{18} \mathrm{O}$ and $\delta \mathrm{D}$, respectively; thus, in 95 percent of repeat analyses the same sample would result in $\delta^{18} \mathrm{O}$ within 0.2 per mil of the originally reported value and the $\delta \mathrm{D}$ values would be within 2 per mil of the originally reported value). Evaporative effects would cause a trend opposite to the observed data; therefore, the trend is likely a function of the origin and season of precipitation events that resulted in streamflow and subsequent infiltration at the downstream sites. Specifically, for the time period represented by the unsaturated zone pore water, it is the longer duration and isotopically lighter winter storms that were more important contributors to infiltration in the downstream reaches than in the upstream reaches. The exception to this trend is at the uppermost borehole near Craycroft Road ((D-13-14)26daa) where the lightest values, a $\delta^{18} \mathrm{O}$ of -10 per mil, and a $\delta \mathrm{D}$ of -65 per mil, were measured. Depth to water at this site, however, is commonly only a few meters below the streambed; therefore, water in the unsaturated zone at the time of core collection probably is representative of infiltration only from the most recent streamflows.

Another trend in the isotopic data is that water from the saturated zone has $\delta^{18} \mathrm{O}$ and $\delta \mathrm{D}$ values that are consistently lighter than those in water from the unsaturated zone and do not reflect evaporation effects as do those in water from the

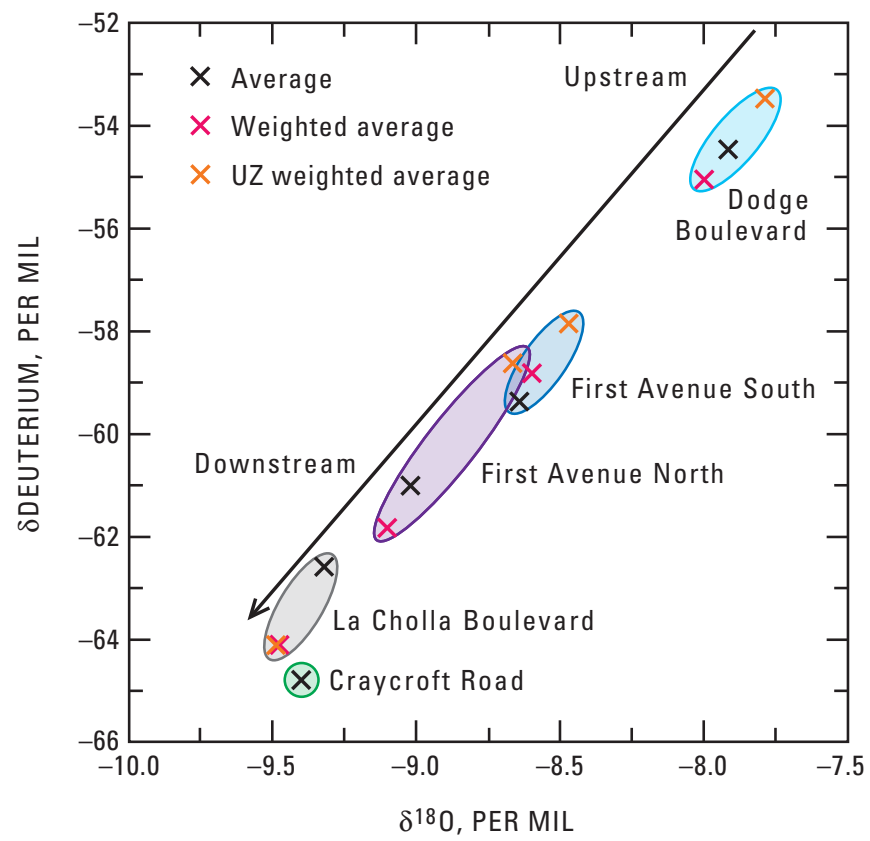

Figure 8. Weighted average of stable isotope values from pore water collected from boreholes along Rillito Creek Pima County, Arizona. 
unsaturated zone (fig. 8). This lighter isotopic composition in the ground water from beneath the water table indicates a greater influence of winter and (or) higher elevation precipitation in the ground water than for the water in the unsaturated zone at the time of collection. The lack of an evaporative signal indicates that water that reaches the water table is exposed to minimal evaporation.

Oxygen-18 $\left(\delta^{18} \mathrm{O}\right)$ and $\delta \mathrm{D}$ data for precipitation in the Tucson Basin collected prior to the study period were analyzed to define a possible isotopic input function to the system. Isotopic compositions for precipitation in the Tucson Basin that resulted in Rillito Creek streamflow indicate that light compositions are associated with the winter $1998 \mathrm{El}$ Niño weather pattern, whereas compositions are varied for the summer precipitation events of 1997 and 1998 (fig. 9).

A substantially heavy isotopic signal was associated with precipitation in April and August 1998. Assuming conservative behavior, isotopic compositions measured in the precipitation are possible event markers that might be identified in the unsaturated zone. In order to identify event markers in the unsaturated zone, vertical profiles of $\delta^{18} \mathrm{O}$ and $\delta \mathrm{D}$ were compared to $\delta^{18} \mathrm{O}$ and $\delta \mathrm{D}$ in samples of runoff (fig. 10). This analysis was done for the borehole near Dodge Boulevard because it is near the streamflow-gaging station at Dodge

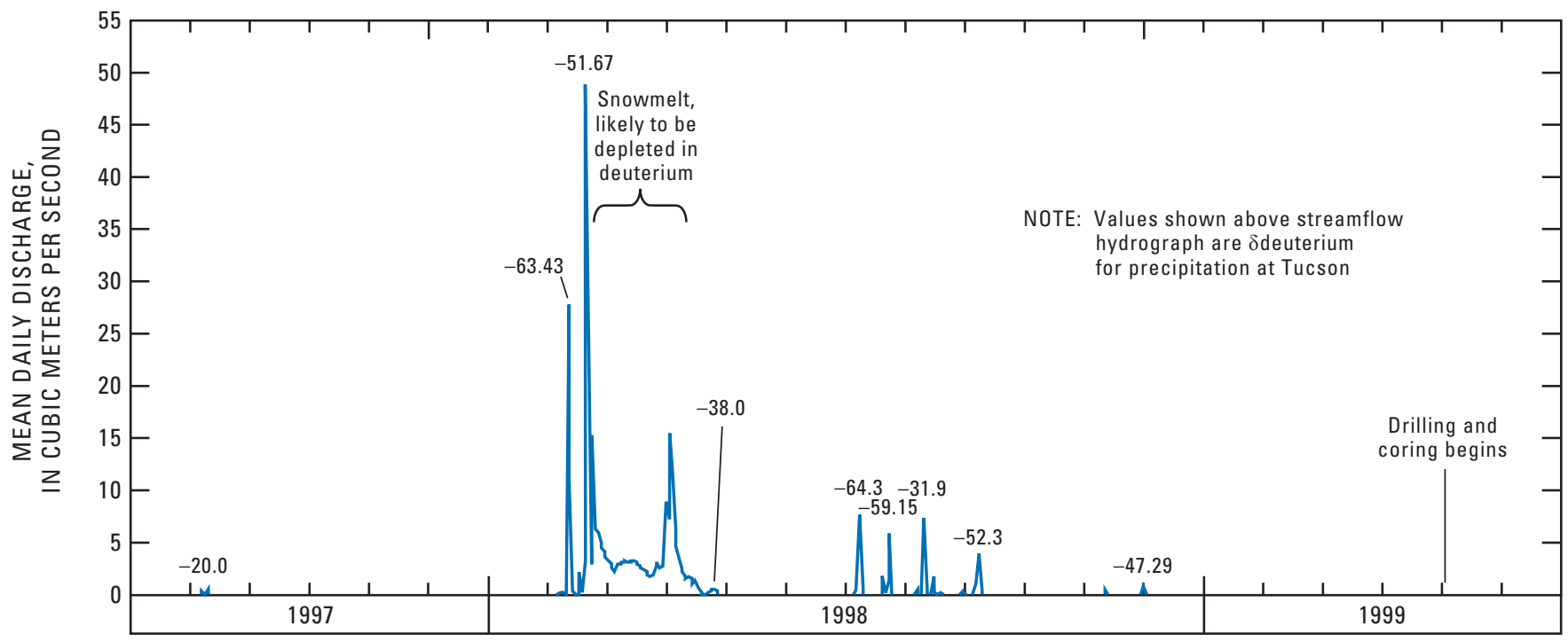

Figure 9. Hydrograph of streamflow gaging station 09485700 Rillito Creek near Dodge Boulevard (09485700) and associated stable isotope values determined for precipitation.

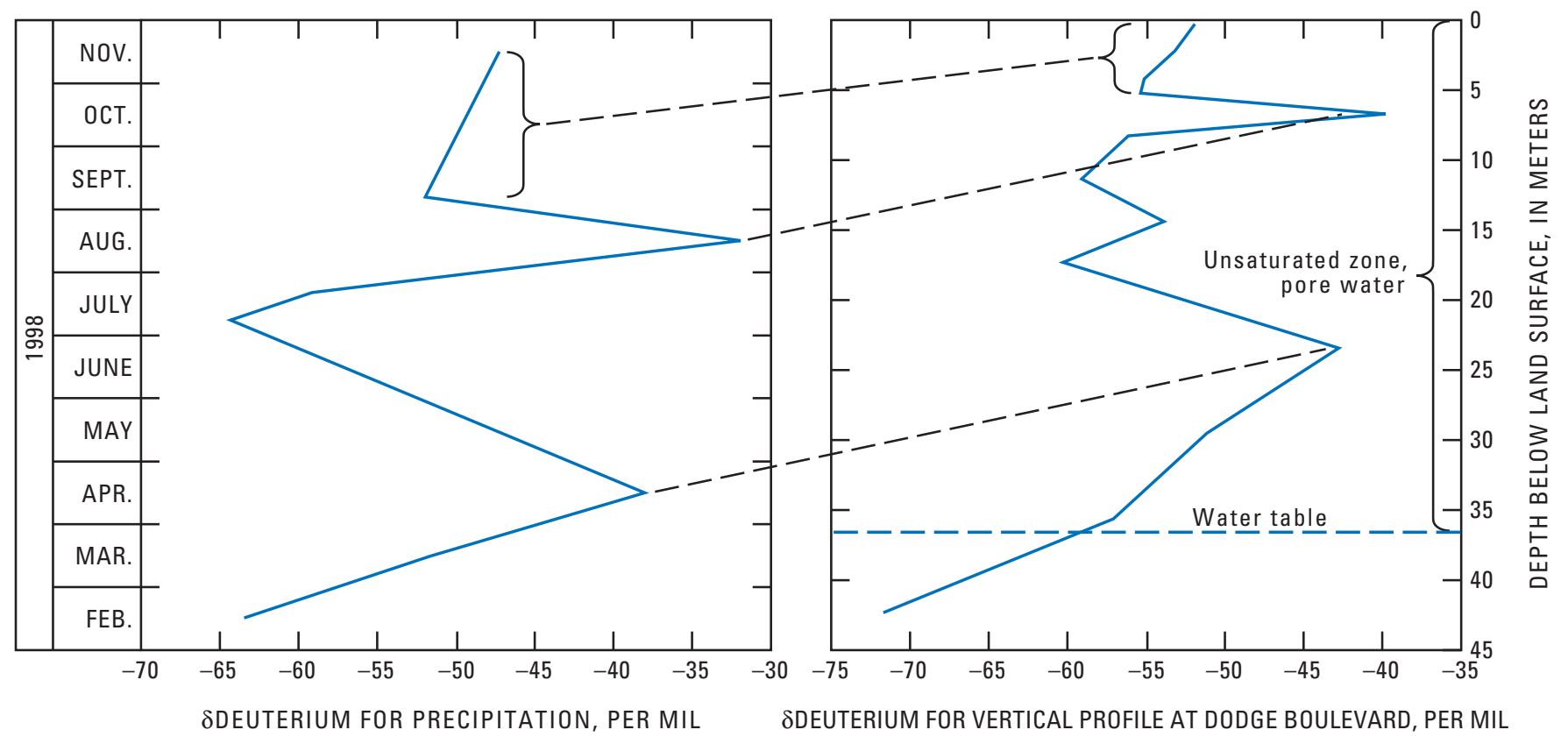

Figure 10. Comparison of stable isotope values in vertical profile to stable isotopic values of precipitation. 
Boulevard (09485700). The hydrograph for this gaging station was used to determine timing of streamflow prior to drilling and coring. The trends in isotopic compositions measured in the pore-water cores approximately match the pattern of signatures in the basin precipitation from particular storms that occurred from February to November 1998. For instance, the heavy isotopic compositions in precipitation in April and August 1998 are possibly identified in pore water from depths of 6.5 and $23 \mathrm{~m}$, respectively (fig. 10). Below $23 \mathrm{~m}$, the compositions become lighter and are similar to those of the El Niño precipitation events about 14 months prior to the drilling and coring. If this interpretation is correct, water in the unsaturated zone below about $23 \mathrm{~m}$ is likely to have originated from sustained flows related to 1998 El Niño precipitation. Discrete pore-water sampling and minor mixing of pore water within the unsaturated zone can explain why the values for precipitation tend to have a wider range $(-32$ to $-65 \delta \mathrm{D})$ than values for the unsaturated zone pore water $(-40$ to $-61 \delta \mathrm{D})$. Correlation between the precipitation events and depths of infiltration, on the basis of corresponding isotopic signatures, indicates an average vertical linear velocity of approximately $0.049 \mathrm{~m} / \mathrm{d}$ at the borehole near Dodge Boulevard. This velocity represents the downward percolation rate of water. Percolation is defined here as the flow of water that has infiltrated and is moving downward or lateral toward the water table. Note that infiltration connotes movement of water into sediments, in contrast to percolation, which connotes movement through sediments. Owing to the decrease in hydraulic conductivity with decreasing water content, the percolation rate is less than the measured saturated hydraulic conductivity.

Chloride concentrations in pore-water leachate were determined from drill cuttings at $0.3-\mathrm{m}$ depth intervals. To derive the leachate, $50 \mathrm{~mL}$ of distilled water was mixed with $50 \mathrm{~g}$ of sieved cuttings having a particle size of less than $1 \mathrm{~mm}$. The mixture was stirred and the specific conductance measured. An ion-specific probe was used to measure the chloride concentration after the specific conductance stabilized. Chloride concentrations are reported for the boreholes near Dodge Boulevard and near First Avenue (fig. 11).

Chloride concentrations at the borehole near La Cholla Boulevard between about 10 and $30 \mathrm{~m}$ are not presented because the fine-grained unit at this depth made leaching and sieving difficult, and therefore the results were suspect. Chloride concentrations are not presented for the borehole near Craycroft Road because of the shallow water table there.

Chloride concentration in runoff varies as a function of the precipitation location and the runoff travel path and surface-contact time. Chloride concentrations measured in the profile varied substantially through the upper $18 \mathrm{~m}$ at all sites (fig. 11). Below about $18 \mathrm{~m}$, the variation in concentration declined considerably. On the basis of $\delta^{18} \mathrm{O}$ and $\delta \mathrm{D}$ data discussed previously, this zone of smaller variation corresponds to the infiltration depth of the 1998 El Niño water. The small variation and low mean chloride concentration are attributed to infiltration from sustained streamflow having a low chloride concentration. In addition, the low chloride concentration indi- cates the water had little exposure to evaporation. The greater variation and higher concentration observed in post-El Niño pore water are likely due to mobilization of chloride from evaporative concentrates and dry fallout on the streambed and tributaries deposited between precipitation events. Calculation of a downward percolation rate using an event marker in the chloride profile at Dodge Boulevard yields an average linear velocity of $0.055 \mathrm{~m} / \mathrm{d}$, and corresponds closely to the rate calculated using the stable-isotope data. On the basis of the environmental tracers measured at the borehole near Dodge Boulevard, pore water in the unsaturated zone represents water that infiltrated into the sediments within the 12 to 14 months prior to drilling, and approximately half of the water (water in the deeper half of the unsaturated zone) infiltrated from the previous El Niño runoff event.

Multiplying the downward percolation rate by the volumetric water content results in the flux of recharge that reaches the water table. Using a percolation-rate estimate of $0.05 \mathrm{~m} / \mathrm{d}$, an average volumetric water content of 13 percent measured in the cores from the borehole near Dodge Boulevard borehole (Hoffmann and others, 2002), and a wetted perimeter of $25 \mathrm{~m}$, results in a flux across the water table of 0.002 cubic meters per second per linear kilometer of streamflow $\left(\mathrm{m}^{3} / \mathrm{s} / \mathrm{km}\right)$.

\section{Seepage Measurements}

Seepage measurements were made at several sites along Rillito Creek during the El Niño-related sustained flows of March through April 1998 to determine infiltration rates for different stream reaches (Don Pool, hydrologist, U.S. Geological Survey, written commun., 2003). Findings from the 1998 seepage measurements are summarized here because, on the basis of stable-isotope ratios and chlorideconcentration profiles, infiltration from the sustained El Niño flow is likely to have provided most of the water stored in the unsaturated zone at the time of borehole drilling and core collection. Streamflow losses owing to infiltration along Rillito Creek ranged from 0.07 to $0.9 \mathrm{~m}^{3} / \mathrm{s} / \mathrm{km}$ and were largest downstream from Swan Road (fig. 1). The small streamflow losses in the upstream area were attributed to rejected recharge; depth to ground water upstream from Swan Road was near land surface after several days of sustained flow, whereas the depth downstream from Swan Road was typically greater than $30 \mathrm{~m}$.

Seepage measurements were made again at four sites along Rillito Creek during an 8-hr period on October 24, 2000. Unlike the 1998 seepage measurements, the October 2000 seepage measurements did not isolate streamflow-infiltration rates relative to Swan Road; however, measured streamflow-infiltration rates generally agreed with those measured in 1998, as they ranged from 0.09 to $0.4 \mathrm{~m}^{3} / \mathrm{s} / \mathrm{km}$ and averaged $0.22 \mathrm{~m}^{3} / \mathrm{s} / \mathrm{km}$ (fig. 12). The October 2000 seepage measurements were made during an 8-hr period along a $14-\mathrm{km}$ reach having an average wetted perimeter of about $25 \mathrm{~m}$. Using a wetted perimeter of $25 \mathrm{~m}$ results in an average infiltration rate of $0.75 \mathrm{~m} / \mathrm{d}$, which is 

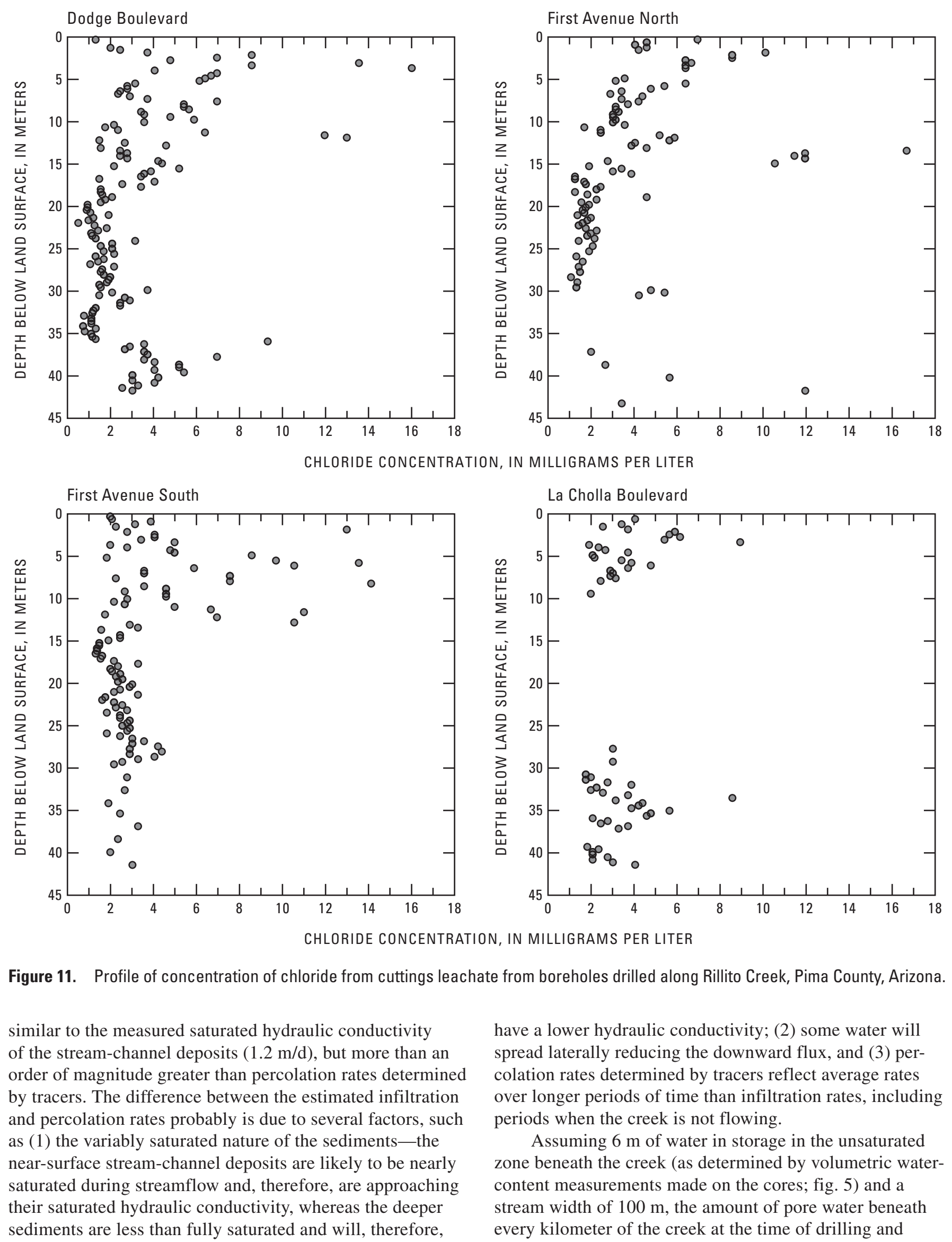
coring was $6 \times 10^{5} \mathrm{~m}^{3}$. There was less water in the upper reach where the unsaturated zone is shallower and more water in the downstream reach where there is an 18-m-thick fine-grained unit having high water content. Assuming an average streamflow loss rate of $0.22 \mathrm{~m}^{3} / \mathrm{s} / \mathrm{km}$, about 33 days of streamflow infiltration would be needed to infiltrate the amount of water stored in the unsaturated zone. There were about 31 days of cumulative flow in the creek in the 12 months prior to drilling and coring; about two-thirds of the flow days were associated with the El Niño snowmelt runoff that occurred about 1 year before the drilling and coring. Assuming the water in the bottom two-thirds of the unsaturated zone collected in 1999 originated from surface water flowing a year earlier, the average downward percolation rate would be about 0.04 to $0.09 \mathrm{~m} / \mathrm{d}$, which brackets the percolation rate estimated by environmental tracers. This analysis of seepage and cumulative streamflow duration required to provide the amount of water held in storage in the unsaturated zone provides an independent method of estimating the age of water in the unsaturated zone, estimating infiltration and percolation rates, and substantiates the interpretation made on the basis of the environmental tracers.

\section{Temperature and Water Content}

\section{One-Dimensional Temperature Monitoring and Modeling}

Heat can be transferred through sediments by a combination of advection and conduction. Although both advective and conductive heat transport occur during infiltration, advective heat transport is more prevalent in high water-flux settings, whereas conductive heat transport is more prevalent in very low or no water-flux conditions. For most hydrologic applications related to infiltration through alluvial sediments, advection is the primary mechanism for the transport of heat by flowing water, and conductive heat transport is regarded as a negligible component of heat transfer (Constantz and others, 2003).

In this study, heat as a tracer was used to estimate onedimensional vertical infiltration by inversely determining the vertical saturated hydraulic-conductivity profiles beneath the streambed. Stream-channel deposits were instrumented with vertical nests of thermistors at three sites along Rillito Creek (fig. 1). Thermographs predicted by numerical simulations were fitted to measured thermographs from the field by adjusting model parameters within appropriate ranges until the least error (best match) was found between simulated and measured thermographs. The three vertical-temperature arrays are buried in the stream-channel deposits near the boreholes (fig. 1). One array is near Craycroft Road in the upper reach of the study area; one is near Dodge Boulevard in the middle reach of the study area; and the other is near First Avenue also in the middle reach of the study area.

The simulation domains for the Rillito Creek models were represented numerically in one dimension, oriented vertically. The upper boundary and datum of the simulation

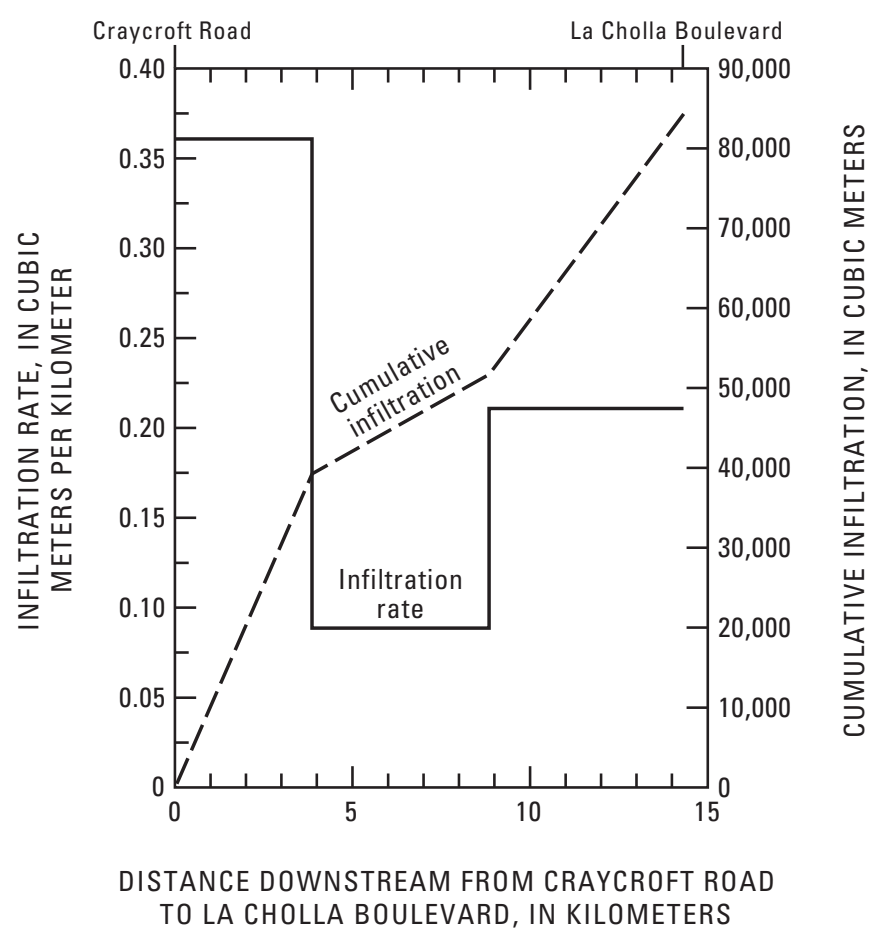

Figure 12. Seepage loses during 0ctober 8, 2000 streamflow in Rillito Creek, Pima County, Arizona.

domains was the streambed. The lower boundary was at or near the depth of the deepest measurements of temperature or pressure, or both. For the simulations, time-varying hydraulic and temperature potentials were defined at the upper- and lower-domain boundaries.

The hydraulic head at the streambed is equivalent to the stream stage. USGS streamflow-gaging stations provided measurements of stage after correction for the datum elevation. Streambed temperatures were measured by thermistors buried about $0.2 \mathrm{~m}$ below the streambed in the most active part of the channel. Pressure-head measurements from piezometers were used to define heads at the lower boundary of the three study sites. The lower-boundary temperatures for the Craycroft Road site were inferred from thermistor measurements near the lower-boundary depth. The lowerboundary temperatures coinciding with the water table for the Dodge Boulevard and First Avenue sites were approximated from ground-water temperatures measured within 5 meters of the water table at those sites. The inverse simulations were made with a numerical coupled water-flow and heat-transport model, VS2DH (Healy and Ronan, 1996), that was linked with parameter estimation software (PEST). A detailed description of the theory, modeling approach, and findings of this investigation is documented in Bailey (2002).

\section{Infiltration at Craycroft Road Site}

Infiltration for two periods of sustained streamflow were modeled for the upstream-most site (near Craycroft 
Road). The first model period extends from July 20, 1999, to July 27,1999 . The second modeled period extends from July 29, 1999, to August 2, 1999. Streamflow and stage at the nearby streamflow-gaging station (Tanque Verde Creek at Tucson) fluctuated between 2.23 and $0.33 \mathrm{~m}^{3} / \mathrm{s}$, and between 0.26 and $0.11 \mathrm{~m}$, respectively, during the first modeled flow period. Streamflow decreased from 1.11 to $0.05 \mathrm{~m}^{3} / \mathrm{s}$ and stage decreased from 0.20 to $0.03 \mathrm{~m}$ during the second modeled flow period. The wetted perimeter of the streambed near the Craycroft Road site during these periods was about $10 \mathrm{~m}$.

The measured thermograph at a depth of $1.2 \mathrm{~m}$ for the first modeled period shows a characteristic sinusoidal pattern that varies between about 24 and $26.5^{\circ} \mathrm{C}$, whereas the thermograph for the second modeled period is generally flat and varies only between 25 and $25.5^{\circ} \mathrm{C}$. Model simulation at the Craycroft Road site approximately reproduced the thermograph of the observed data for both model periods (fig. 13). Model simulations were optimized on vertical saturated hydraulic conductivity. Simulated vertical saturated hydraulic-conductivity values were in general agreement with those measured in the laboratory (Bailey, 2002; Hoffmann and others, 2002). A physical change within the streambed between flow periods at this site required the addition of a thin surface layer having a low vertical hydraulic conductivity within the model domain. The addition of this surface layer resulted in a lowering of the simulated equivalent saturated hydraulic conductivity by four orders of magnitude, from about $4 \mathrm{~m} / \mathrm{d}$ to $3 \times 10^{-4} \mathrm{~m} / \mathrm{d}$. The four orders of magnitude change in hydraulic conductivity is too large to result solely from changes in water viscosity owing to temperature changes. Given the tranquil flow conditions during the first flow period, it is possible that the change was the deposition of a fine-grained layer at the streambed surface. In fact, a thin layer of fine-grained material commonly was observed at the Craycroft Road site after small streamflow events.

Flow in the creek typically resulted in hydraulic connection between streamflows and ground water (see section titled "Water-Level Responses"). Thus, vertical gradients measured at the vertically nested piezometer at the borehole near Craycroft Road enabled estimation of infiltration rates using simulated equivalent vertical saturated hydraulic conductivity. Vertical hydraulic gradients measured from these piezometers typically ranged from 0.06 to $0.2 \mathrm{~m} / \mathrm{m}$ and averaged $0.1 \mathrm{~m} / \mathrm{m}$. The highest gradients occurred during and shortly after streamflow. Assuming a typical gradient during and shortly after streamflow $(0.2 \mathrm{~m} / \mathrm{m})$ and a wetted perimeter of $10 \mathrm{~m}$, estimated infiltration rates ranged from $0.09 \mathrm{~m}^{3} / \mathrm{s} / \mathrm{km}$ during the first modeled period to $8 \times 10^{-6} \mathrm{~m}^{3} / \mathrm{s} / \mathrm{km}$ during the second modeled period. The first modeled period is probably most representative of the typical ephemeral-streamflow conditions; the second period of streamflow modeled is probably most representative of small flows that occur after a layer of fine-grained deposits has been deposited. The infiltration rate of $0.09 \mathrm{~m} / \mathrm{s} / \mathrm{km}$ for the first modeled period is about half of that estimated by seepage measurements (average of $0.21 \mathrm{~m}^{3} / \mathrm{s} / \mathrm{km}$ ).

\section{Infiltration at Dodge Boulevard and First Avenue sites}

Infiltration also was modeled for two time periods at the Dodge Boulevard and First Avenue sites: the first modeled period extends from July 14, 1999, to July 17, 1999, and the second modeled period extends from July 25,1999 , to July 29,1999 . The proximity of the thermistors to the streamflow-gaging station 09485700 at Dodge Boulevard allowed direct use of the gaging-station measurements to define the hydraulic head at the upper boundary within the Dodge Boulevard model domain. These boundary conditions also were used for the First Avenue model domain. Discharge and stage for these two periods reached maximums of $254 \mathrm{~m}^{3} / \mathrm{s}$ and 2.7 $\mathrm{m}$, respectively. The wetted perimeter for these flows was about $10 \mathrm{~m}$. An important difference between these sites and the site near Craycroft Road is that the depth to the water table near the Dodge Boulevard and First Avenue sites is greater than $30 \mathrm{~m}$; therefore, ephemeral flow in the stream channel at these sites may never result in hydraulic connection between the stream and the aquifer.

Thermographs from a depth of $0.8 \mathrm{~m}$ at the Dodge Boulevard site for the two modeled periods have contrasting signals. The thermograph for the first period shows a decline in temperature associated with streamflow from about 29.5 to $20.5^{\circ} \mathrm{C}$ that is followed by a gradual increase to $26^{\circ} \mathrm{C}$; the thermograph for the second period shows a rapid increase in temperature associated with streamflow from about 29 to $32^{\circ} \mathrm{C}$ that is followed by a gradual decrease to $27^{\circ} \mathrm{C}$ (fig. 14). The most accurate prediction of the observed thermograph for the first modeled time period at the Dodge Boulevard site resulted in an equivalent vertical saturated hydraulic conductivity of about $5 \mathrm{~m} / \mathrm{d}$, which is similar to, yet slightly higher than, the equivalent vertical saturated hydraulic conductivity simulated at the Craycroft Road site. Vertical hydraulic gradients were not measured at the Dodge Boulevard site, thus, infiltration rates can not be estimated; however, by assuming a vertical gradient of $0.2 \mathrm{~m} / \mathrm{m}$ (on the basis of the measured gradient at the Craycroft Road site), an equivalent vertical hydraulic conductivity of $5 \mathrm{~m} / \mathrm{d}$, and a wetted perimeter of $10 \mathrm{~m}$, the infiltration flux was calculated as $0.12 \mathrm{~m}^{3} / \mathrm{s} / \mathrm{km}$.

To match the simulated thermograph to the measured thermograph for the second modeled period, a thin surface layer having a low-vertical hydraulic conductivity needed to be added during the modeled period. During the first part of the second simulation, the equivalent vertical saturated hydraulic conductivity was $0.7 \mathrm{~mm} / \mathrm{s}$, which, if sustained, would equate to $66 \mathrm{~m} / \mathrm{d}$. After about 3 hours of streamflow, the addition of the low-conductivity surface layer reduced the equivalent vertical hydraulic conductivity to about $0.25 \mathrm{~m} / \mathrm{d}$. The decrease in hydraulic conductivity during a flow event is consistent with the deposition and accumulation of fine sediments on the receding limb of a hydrograph.

Model simulations for the site near First Avenue relied on stage data from the streamflow gaging-station 09485700 at Dodge Boulevard (Bailey, 2002). Simulations for this site covered the same two time periods and resulted in equivalent 


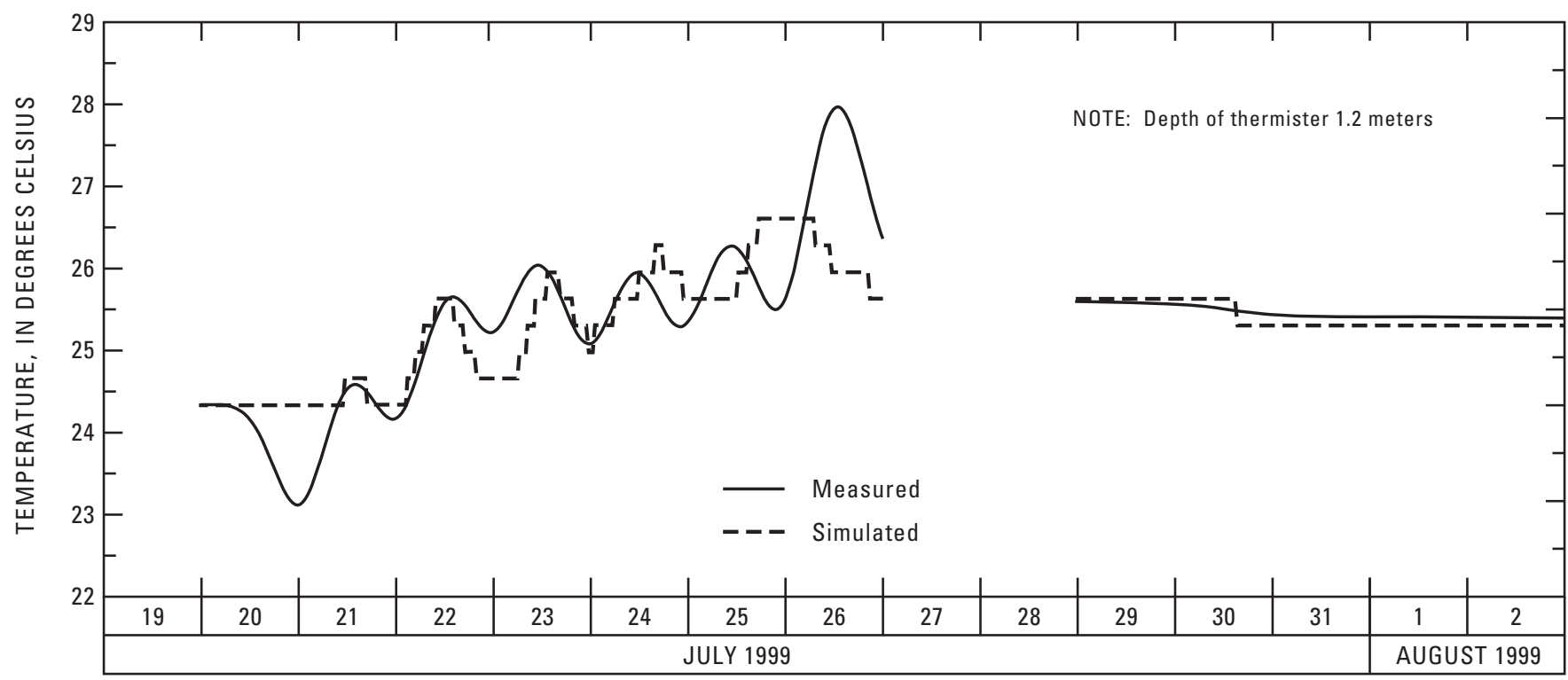

Figure 13. Measured and simulated thermographs in Rillito Creek near Craycroft Road, Pima County, Arizona.

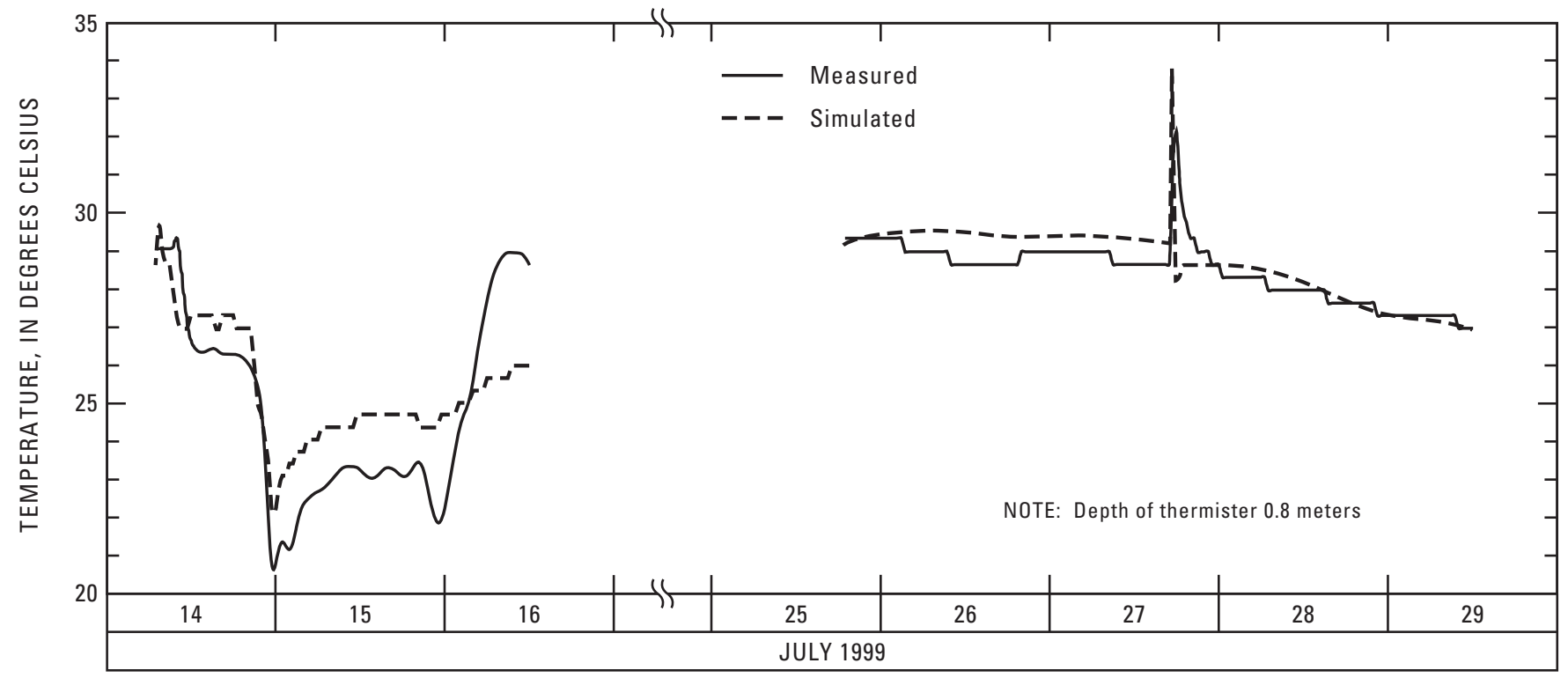

Figure 14. Measured and simulated thermographs in Rillito Creek near Dodge Boulevard, Pima County, Arizona.

vertical hydraulic conductivity values that were similar to those estimated for the site near Dodge Boulevard. In addition, the simulation for the second modeled period required the addition of a low vertical hydraulic conductivity surficial layer during the latter part of the period. The model simulations for the site near First Avenue, however, were less successful in matching the observed data than the simulations for the site near Dodge Boulevard. The inability of the simulations to match the magnitude and changes in the temperature measured at the site near First Avenue indicates the numerical model likely is not representing some of the infiltration processes, such as multidimensional flow beneath the streambed, the model has poorly constrained sediment and hydraulic parameters, or a combination of these factors.

Results of this investigation indicate that, under well-constrained conditions where predominantly vertical infiltration can be assumed, a one-dimensional inverse numerical model can be used to estimate infiltration rates. One-dimensional modeling, however, assumes lateral spreading does not occur. If lateral spreading does occur, the estimated rates predicted by one-dimensional modeling will be smaller than actual rates. The results also indicate that streambed hydraulic conductivity can limit infiltration and that hydraulic conductivity can vary significantly between and during flow events. Erosion 
and deposition associated with low-frequency, high-intensity ephemeral streamflow can result in large variations in the hydraulic conductivity of the streambed surface owing to an accumulation or removal of fine-grained sediments. This variability affects the cumulative infiltration, which could vary greatly as a function of the amount of streamflow and a function of the nature of the streamflow and the accumulation or removal of fine-grained sediments. Additionally, these results indicate that simulation of streambed infiltration should allow for temporal variation of the streambed hydraulic conductivity or should be done using short time periods to account for rapid changes in the streambed hydraulic conductivity.

\section{Two-Dimensional Temperature and Water- Content Monitoring}

For the purpose of measuring infiltration fluxes at the onset and throughout the duration of streamflow events, Blasch and others (2003) instrumented the stream-channel deposits beneath Rillito Creek near Dodge Boulevard with a two-dimensional vertical array of 28 paired thermocouples, temperature probes, and time-domain reflectometry (TDR) water-content probes placed perpendicular to flow (fig. 1). The paired probes were arranged in four columns (profiles $\mathrm{C} 1, \mathrm{C} 2$, $\mathrm{C} 3$, and $\mathrm{C} 4$ in figure 1) spaced $3 \mathrm{~m}$ apart. There are seven rows (depths) within the array at depths of about 0.50, 0.75, 1.0, $1.25,1.50,2.0$, and $2.5 \mathrm{~m}$ below the streambed. Depths of the probes varied by as much as $0.25 \mathrm{~m}$ owing to deposition and erosion during flow events. A near-surface temperature sensor also was placed adjacent to the paired two-dimensional array at a depth of $0.05 \mathrm{~m}$.

The highly transient conditions that exist during the onset of streamflow are more difficult to simulate using temperature measurements exclusively than the saturated conditions presented in the previous section because of the rapid changes in water fluxes and increased multidimensional infiltration. Combined water-content and temperature measurements are needed to simulate initial transient infiltration rates in unsaturated sediments. Additionally, infiltration rates can be estimated using wetting-front arrival times and changes in water content at successive TDR probes.

Water-content data show rapid changes shortly after the onset of streamflow (fig. 15). Volumetric water content increases throughout the measured profiles from about 20 percent to 40 percent within minutes of the onset of streamflow. Initial infiltration rates measured as the change in volumetric water content over time per unit area were as high as $2 \mathrm{~mm} / \mathrm{s}$, which if sustained would be equivalent to $166 \mathrm{~m} / \mathrm{d}$. The high rates are likely to include vertical and lateral flow components. Temperature and water-content data for a September 2000 event indicate that infiltration occurs in both the horizontal and vertical directions at the onset of streamflow (figs. 16 and 17). Measured lateral wetting-front velocities between profiles were similar in magnitude to vertical velocities. The similar velocities measured at the onset of streamflow probably were due to tension gradients being much larger than the gravitational gradient. Water traveled laterally almost the entire 9-m

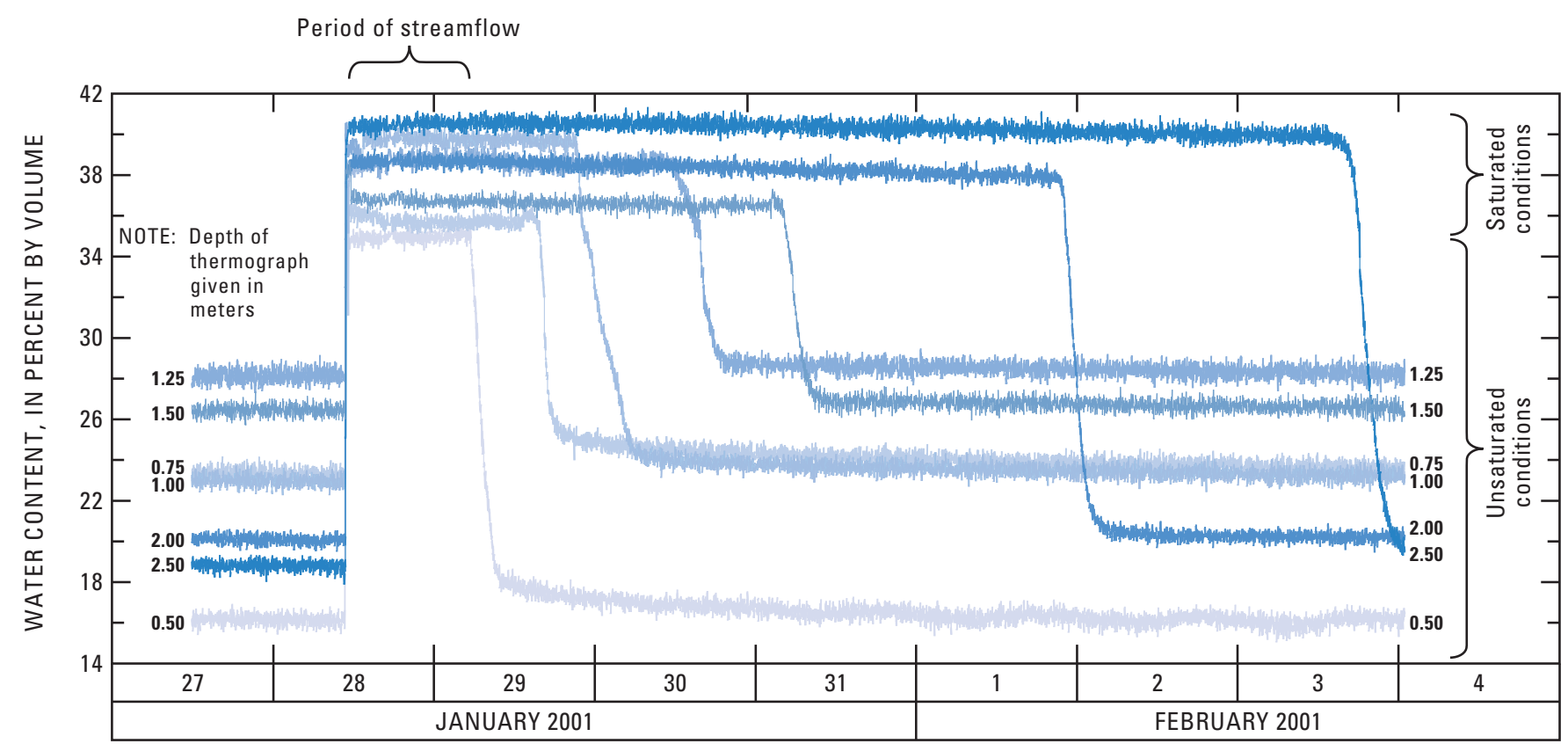

Figure 15. Water content of stream-channel sediments for duration of a streamflow event including onset and cessation, from within two-dimensional array in Rillito Creek near Dodge Boulevard, Pima County, Arizona. 
distance between profiles within the first few minutes of the onset of streamflow.

Multidimensional-flow simulations are required to accurately represent the full volume of water infiltrating into a porous, heterogeneous medium near the margins of the advancing wetting front where capillary flow dominates. Infiltration, however, is increasingly vertical near the center of streamflow in a homogeneous medium, and lateral flow diminishes as capillary gradients decline with distance from the boundary of the wetted perimeter. The time from the onset of flow required for vertical infiltration to dominate varies depending on streamflow conditions and the texture of the streambed material. For instance, small braided-ribbon flows over fine material may never result in predominantly vertical infiltration, whereas large bank-to-bank flows over coarse material may produce predominantly vertical infiltration beneath the streambed within minutes on the basis of the large wetted perimeter and conductivity of the sediments.

A typical set of measured Rillito Creek thermographs from an April 2001 event and from a November 2000 event were simulated using a variably saturated heat and mass transport model, VS2DH (Healy and Ronan, 1996). The thermographs for the 0.5 - and 2.5-m depths were used as boundary conditions, and the thermographs for the remaining five depths were used as observation points. One-dimensional models were created. Parameter optimization software, PEST, was used to calibrate thermal and hydraulic properties. Numerical simulations shown for data from the two-dimensional array are for a 10-m wide flow event starting on April 6, 2001 (fig. 18). The assumption of vertical one-dimensional flow was considered valid because temperature changes were predominantly in the vertical direction. The simulated infiltration rates varied from about 0.35 to $0.39 \mathrm{~m} / \mathrm{d}$ throughout the initial 2 days of flow (fig. 19) and average $0.37 \mathrm{~m} / \mathrm{d}$. This represents a variation in predicted infiltration rates of less than 10 percent among the four columns, indicating that infiltration was uniform and predominantly vertical. Although the simulated and measured thermographs are in general agreement, departures do exist. Simulated temperatures differ from measured temperatures for several reasons, such as error in the measured boundary conditions, error in hydraulic and thermal property assignments, or an inability of the models to fully represent multidimensional infiltration.

The infiltration rate generally declines as the streamflow event proceeds. The declining infiltration rate is attributed to a declining pressure head and (or) development of a thin, finegrained surface layer. Infiltration rates continued to decline during the flow event and averaged $0.32 \mathrm{~m} / \mathrm{d}$ for the 12 days measured. By converting to flux units that are comparable with those estimates made at the vertical temperature nests described above and using a wetted perimeter of $10 \mathrm{~m}$, an average infiltration rate of $0.32 \mathrm{~m} / \mathrm{d}$ equates to a flux of 0.04 $\mathrm{m}^{3} / \mathrm{s} / \mathrm{km}$. There are two important differences between these estimates and estimates made at the one-dimensional temperature-array sites near Craycroft Road and Dodge Boulevard. First, the estimated infiltration rates at the vertical-array sites near Craycroft Road and Dodge Boulevard are about twice that of the infiltration estimates made at the two-dimensional array. Second, the infiltration rates at the vertical-array sites required a low-hydraulic conductivity layer be incorporated into the model in the later stages of infiltration. The addition of a low-conductivity layer resulted in significantly reduced infiltration rates during the later stages of streamflow. The two-dimensional array was at the lowest part of the cross section, whereas the vertical nest was near a depositional fringe within the streambed, which may account for the deposition of the low-conductivity layer at the vertical nests.

An estimated sustained infiltration rate of about $0.32 \mathrm{~m} / \mathrm{d}$ for the April 2000 streamflow event agrees with simulation results for a November 2000 event lasting 10 days. An average infiltration rate of $0.37 \mathrm{~m} / \mathrm{d}$ was simulated for the November event. These rates show general agreement with infiltration rates of 0.41 to $0.50 \mathrm{~m} / \mathrm{d}$ estimated by other investigators along Rillito Creek (Burkham, 1970; Katz, 1987). Simulations were also extended about 2 days beyond the periods of streamflow to estimate the redistribution of water in the subsurface. Redistribution rates, similar to infiltration rates, are determined from the elapsed time between sharp decreases in water content at each depth (fig. 15). After the cessation of streamflow, temperature measurements indicated the simulated dewatering flux was 0.33 and $0.30 \mathrm{~m} / \mathrm{d}$ for the April and November events, respectively. Estimated redistribution rates using water-content changes were 0.08 and $0.1 \mathrm{~m} / \mathrm{d}$ for the April and November events, respectively. Thus, redistribution rates were slightly less than infiltration fluxes during steady-state flow, and estimates of dewatering using water-content measurements were less than the simulated fluxes using temperature methods.

The variety of physical and chemical methods presented in this chapter (and elsewhere) are used to estimate rates of infiltration and percolation under steady-state conditions. For long-duration events (several days to months) steady-state conditions may be an accurate assumption, but for short-duration events (less than $24 \mathrm{hrs}$ ) typical of those in Rillito Creek and other streams in southern Arizona, infiltration fluxes that occur shortly after the onset of flow may differ substantially in magnitude from those throughout the duration of the event. For detailed water-budget analyses and hydrologic models dependent on infiltration flux estimates, the infiltration flux has to be estimated more accurately than is possible when using the assumption of steady-state conditions. Infiltration fluxes through the first $2 \mathrm{~m}$ of unsaturated sediments at the onset of streamflow calculated for 20 events ranged from 13 to $166 \mathrm{~m} / \mathrm{d}$. Variability in antecedent water content and fluid temperature were examined as possible factors contributing to the range in onset fluxes. Onset infiltration rates were inversely correlated to antecedent water content with a log-linear relation (fig. 20). Measured onset infiltration fluxes differed from those of the steady-state infiltration fluxes by four orders of magnitude. Infiltration rates after onset declined more quickly for events in which the antecedent water content was high; events starting with higher antecedent water content required 3.7 hours to achieve near steady-state conditions, whereas events with lower antecedent water content required $6.8 \mathrm{hrs}$. 


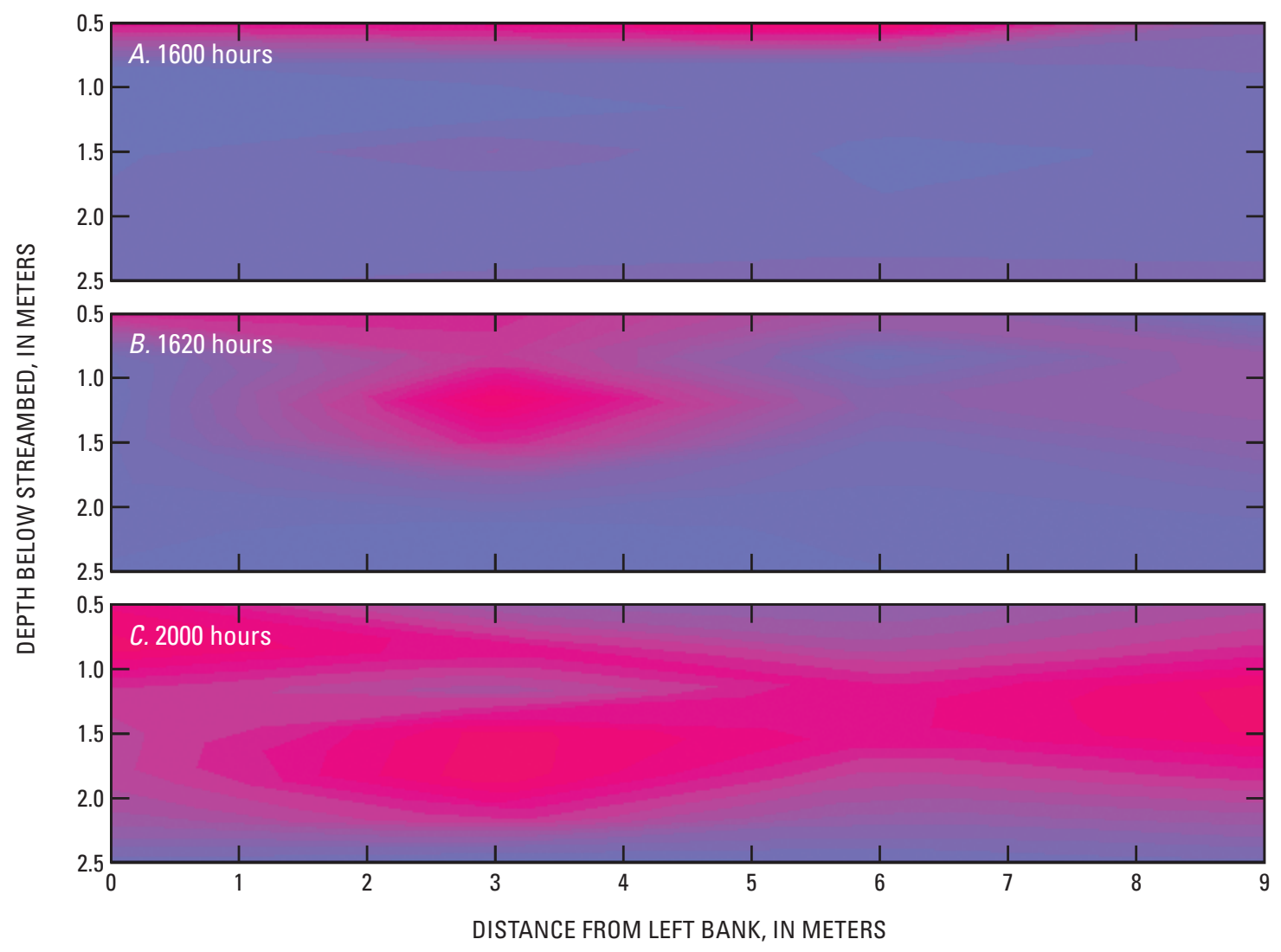

EXPLANATION

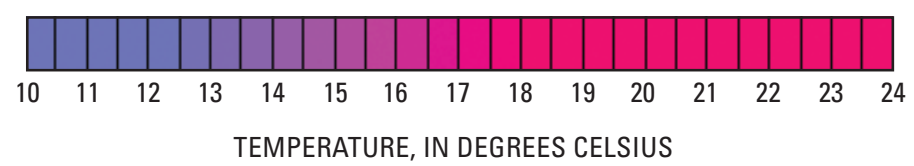

Figure 16. Two-dimensional distribution of temperature during different streamflow conditions in Rillito Creek on September 10, 2000, near Dodge Boulevard, Pima County, Arizona. A, Thermal transport through conduction before the onset of streamflow; $B$, thermal transport through a combination of advection and conduction at the onset of streamflow exhibiting multidimensional flow through the sediments; $C$, combined advection and conduction thermal transport to the deeper sediments several hours after the onset of streamflow. 

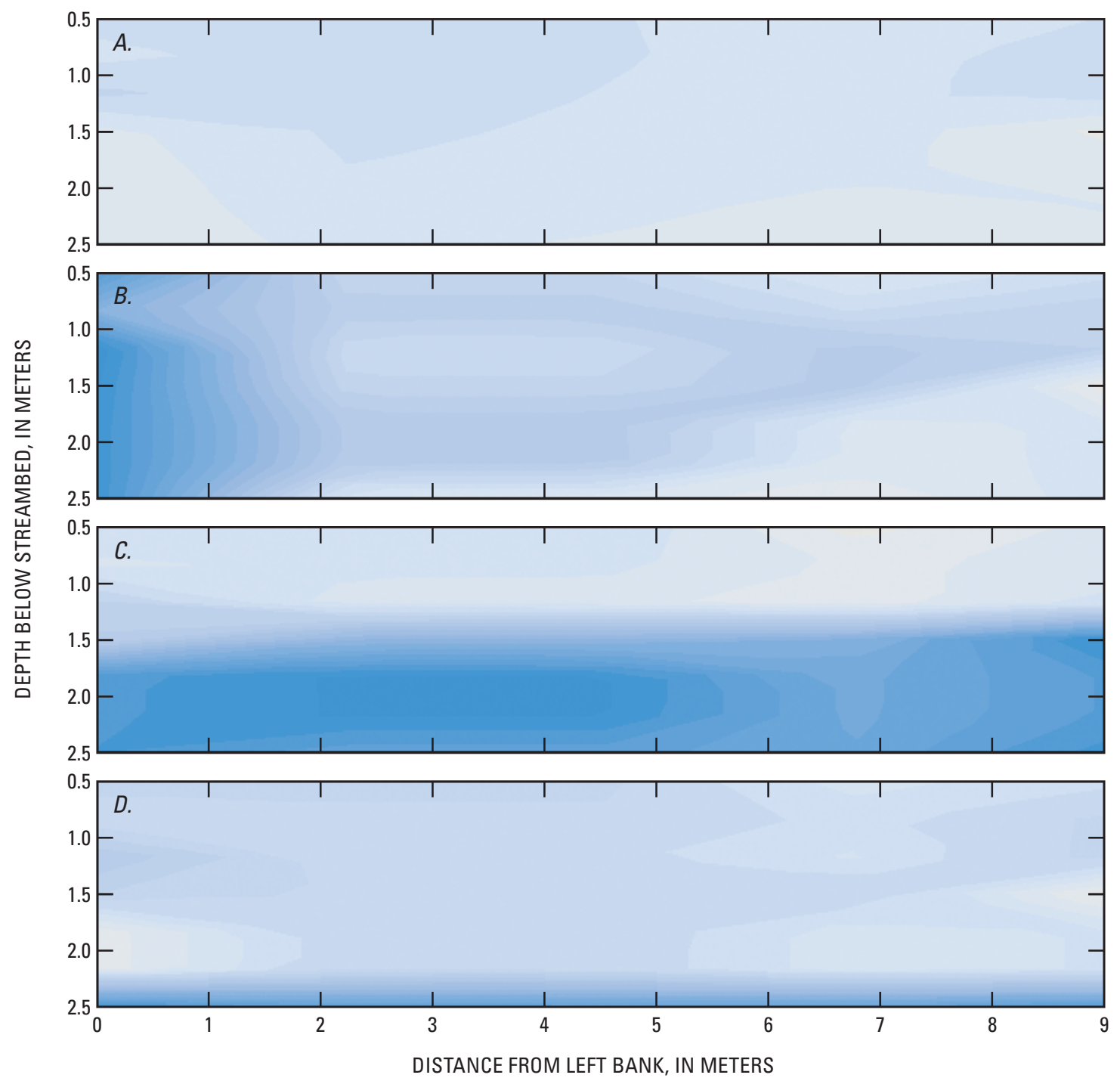

EXPLANATION

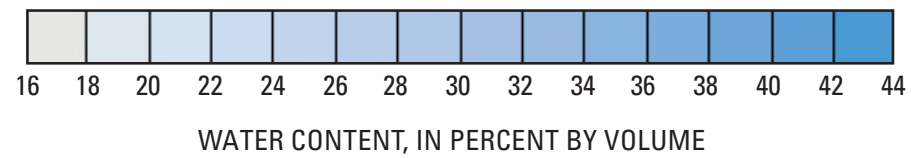

Figure 17. Two-dimensional plot of soil-water content during different streamflow conditions in Rillito Creek near Dodge Boulevard, Pima County, Arizona; $A$, Before the onset of streamflow, September 10, 2000, at 1600; $B$, five minutes after the onset of streamflow, September 10, 2000, at 1605; $C$, immediately after the cessation of streamflow September 12, 2000; $D$, approximately 2 days after the cessation of streamflow, September 14, 2000. 


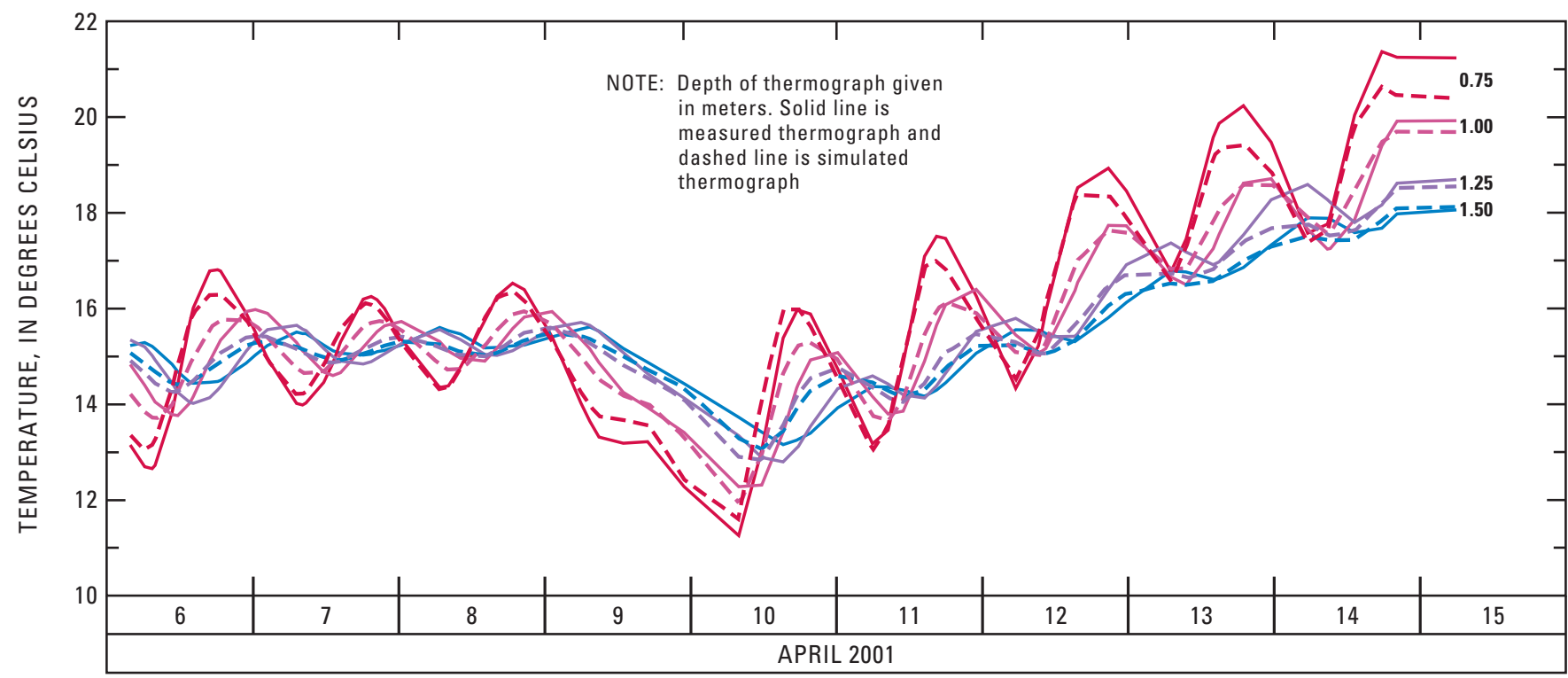

Figure 18. Typical measured and simulated thermographs from two-dimensional temperature array from column 1 (see fig. 1 for column location) in Rillito Creek near Dodge Boulevard, Pima County, Arizona.

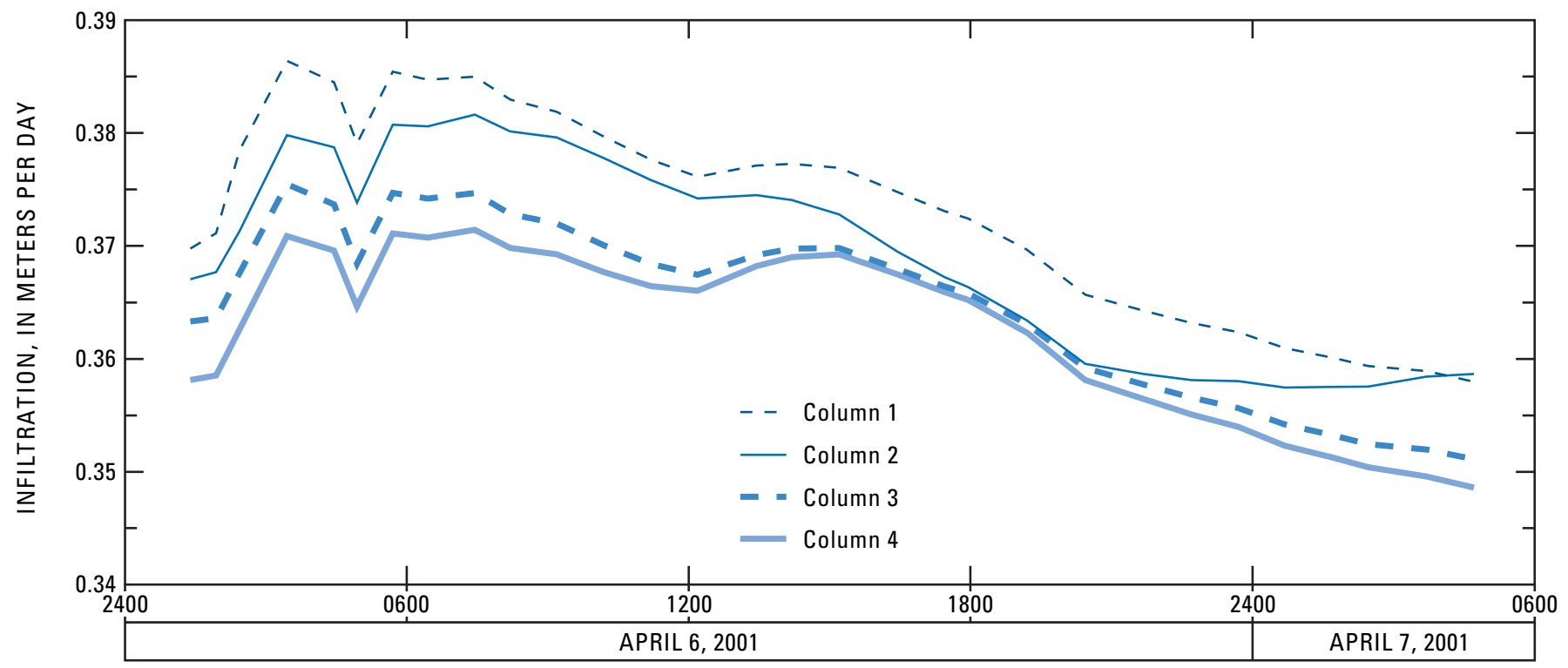

Figure 19. Simulated infiltration rates during period of flow at the two-dimensional temperature array near Dodge Boulevard, Pima County, Arizona.

The general agreement in infiltration estimates among these independent temperature and water-content methods indicates that these methods provide accurate estimates of infiltration. As such, vertical arrays of temperature probes can be located along stream reaches to estimate the potential for in-stream recharge and to provide guidance on citing recharge facilities. High infiltration rates at shallow depths, however, are not sufficient to ensure that water will percolate to deeper depths and recharge the deep aquifer at a high rate. Infiltration rates determined from shallow measurements should be considered an upper limit of the potential recharge rate for a particular site.

\section{Water-Level Responses}

Piezometer nests were installed in the stream-channel boreholes and monitored for water-level variations in response to streamflow. Nested piezometers included one shallow piezometer completed in what is usually the unsaturated zone, 


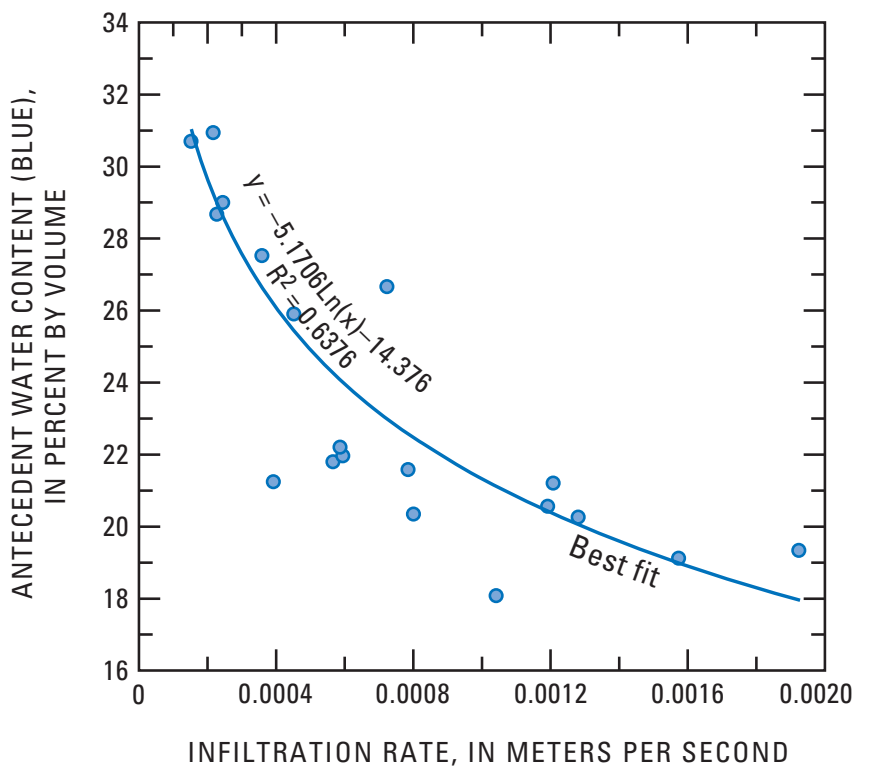

Figure 20. Correlation of onset infiltration rate to antecedent water content.

near the contact between the recent stream-channel alluvium and the basin-fill deposits, and a pair of deep piezometersone near the water table and one about $10 \mathrm{~m}$ below the water table. With the exception of the piezometer near Craycroft Road, the shallow piezometers generally were dry except shortly after streamflow (fig. 21) and contained water for periods of days to several weeks. The magnitude of water-level variation and the period of time the shallow wells contained water varied. For instance, the water level in the shallow piezometer near Dodge Boulevard varied the least (usually less than $1 \mathrm{~m}$ ), whereas the water level in the shallow piezometer near La Cholla Boulevard varied the most (usually between 6 and $7 \mathrm{~m}$ ); water-level variations in the shallow piezometer near First Avenue were usually between 2 and $6 \mathrm{~m}$. Duration in which the water level remained above the bottom of the piezometer was longest in the piezometer near La Cholla Boulevard where saturation persisted for 6 months after the summer 1999 streamflow and 12 months after the winter 2000 streamflow; saturation time was shortest at the shallow piezometer near Dodge Boulevard where it was typically less than 2 months (fig. 21). The long duration of saturation at the shallow piezometer near La Cholla Boulevard probably was due to the fine-grained unit at depth of about 12 to $30 \mathrm{~m}$ (Hoffmann and others, 2002).

Water levels in each of the pairs of deep piezometers responded several days to weeks later than the shallow piezometers and generally after the shallow piezometers became dry. There were little to no vertical gradients measured in the pairs of deep piezometers. These responses suggest gravity flow predominates, and that no hydraulic connection is established between streamflow and the underlying deep aquifer. Given the low-permeability of the basin-fill deposits, relative to that of the stream-channel deposits, it also is likely that temporary perched conditions existed near the contact between these two units for a period of several days to weeks after cessation of streamflow.

Water levels in the deep piezometers showed an overall decline during the period of investigation. Water-level declines between spring 1999 and summer 2002 ranged from about $2 \mathrm{~m}$ at the deep piezometer near Craycroft Road, to $8 \mathrm{~m}$ at the deep piezometer near Dodge Boulevard (fig. 21). The declines probably are related to ground-water pumpage from the basin-fill aquifer. Superimposed on the declines are a series of rises that range from about 0.5 to $3.9 \mathrm{~m}$. These rises are in response to the two most significant streamflow periods that occurred in summer 1999 and fall/winter 2000.

The initial response of the water table in the deep piezometers lags the onset of streamflow by about 2 weeks at the piezometer nests near Dodge Boulevard and near First Avenue, whereas the initial response of the water table at the piezometer nests near Craycroft Road and near La Cholla Boulevard is more rapid-within about a day of streamflow in summer 1999. Lag time for the initial response at the piezometers near Dodge Boulevard and near First Avenue is related to the presence of a thick unsaturated zone at these sites. The short lag time between the onset of streamflow and the initial water-table response could be related to factors such as preferential flow and uniformly high water content throughout the unsaturated zone (Hoffmann and others, 2002). The occurrence of preferential flow is supported by the rapid response of the water table to streamflow despite the presence of the fine-grained unit.

Timing of the water-level peak also varies with location, and the peak occurs several weeks to months after the onset of streamflow. The longest lag time for the peak occurs near La Cholla Boulevard where it was about 7 months. Dissipation to prerecharge-event water levels also required several months at each site (fig. 21).

The magnitude of the water-table response in the deep piezometers is greatest at the piezometer nests near Dodge Boulevard and First Avenue. The water-table response in the piezometer nest near Craycroft Road is reduced relative to the water-table responses near Dodge Boulevard and First Avenue. Shallow piezometers near Craycroft Road indicate the water table often reaches land surface during streamflow events; therefore, the reduced water-level response probably is related to rejected recharge. The magnitude of the watertable response at the piezometer nest near La Cholla is the smallest and is related to a smaller recharge rate related to less frequent and smaller streamflows near La Cholla, relative to the other sites, and the presence of the fine-grained layer in the unsaturated zone. The lack of vertical gradients between the middle and deep piezometers at each nest indicates flow is predominantly horizontal in the saturated zone, except in the piezometer nest near Craycroft Road where the vertical gradient averages about $0.1 \mathrm{~m} / \mathrm{m}$.

A series of recharge estimates were calculated on the basis of the water-level responses using an analyti- 


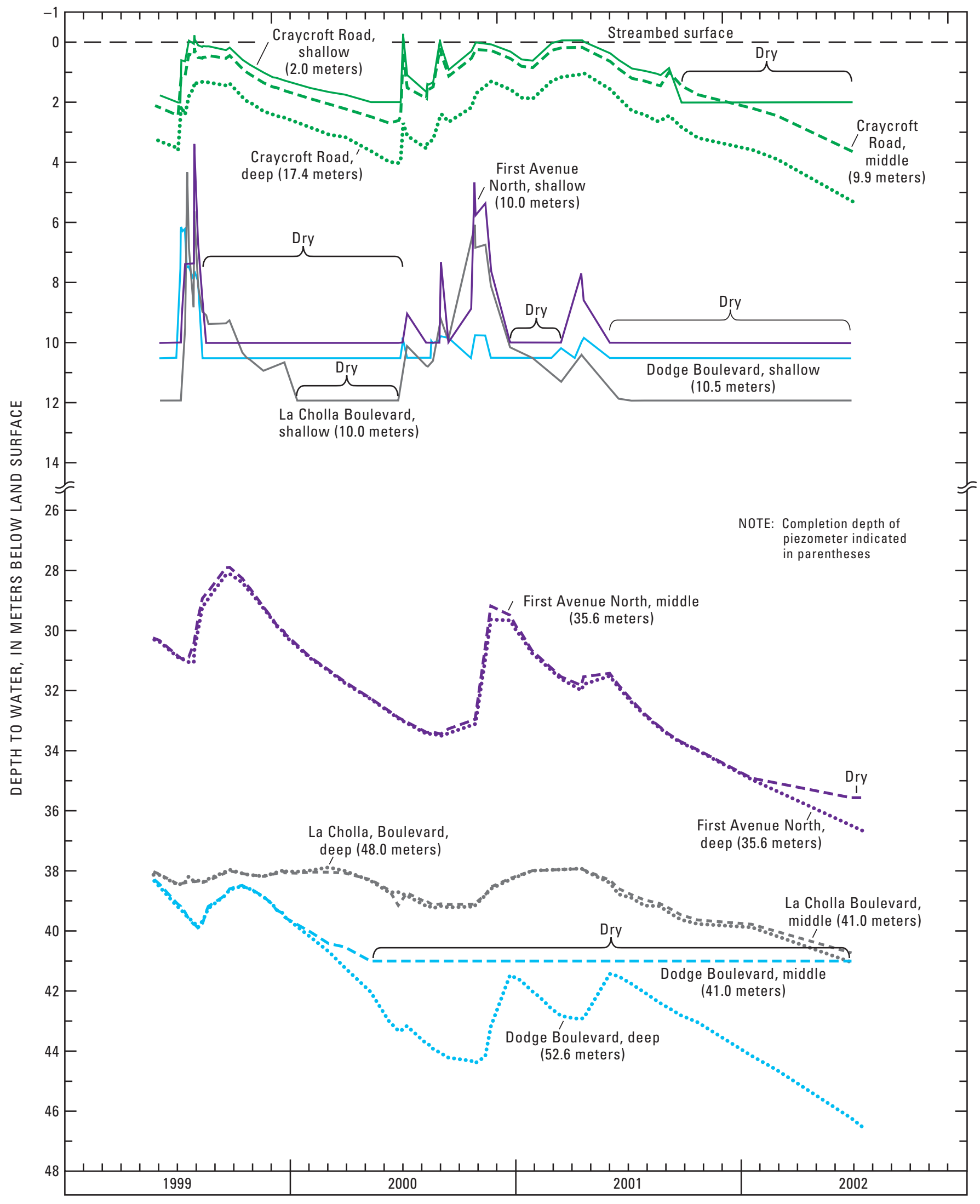

Figure 21. Hydrographs of selected piezometers within Rillito Creek, Pima County, Arizona. 
cal approach developed by Moench and Kisiel (1970). In this analytical model, changes in water levels over time near an ephemeral-stream channel are assumed to reflect actual recharge. This is advantageous in that no information or assumptions regarding unsaturated-zone processes are required in order to make the calculations.

For any given streamflow event, a certain amount of water may recharge the aquifer and thereby cause water levels in nearby wells to rise. The water-level rise results in a mound that slowly dissipates normal to the line source. Subsurface sediments will act to slow the dispersal. The variation in rate and duration of recharge can thus be viewed as an input function, the aquifer as a filter or impulse-response function, and the water levels as output. The variation in the rate and duration of recharge can be calculated from a combination of water-level data and the impulse-response function, which is derived from parameters of aquifer geometry, aquifer storage, and hydraulic properties, using the groundwater flow equations. By summing these rates of recharge for the time period being studied, the volume of water recharged can be determined.

Various assumptions about the aquifer flow-system are required to implement the analytical model deveolpoed by Moench and Kisiel (1970). Flow is assumed to be one dimensional and horizontal. The aquifer is assumed to be homogeneous and isotropic, to be infinite in horizontal extent, and to receive recharge from a finite width source. Aquifer characteristics are assumed to be invariant with time and water-level fluctuations.

Input to the model includes temporal variations in water levels, channel width, distance of the well from the center of the stream channel, specific yield, and transmissivity. The output is recharge calculated as cubic meters per second per linear kilometer of stream channel $\left(\mathrm{m}^{3} / \mathrm{s} / \mathrm{km}\right)$ over the period of record. Variations in measured water levels were assumed to be recharge events superimposed upon a generally declining water table. In order to find the amount of water recharged without the bias of the decline, the data were detrended (fig. 22). Detrending consisted, first, of calculating the trend in the data using a linear regression. This trend was then removed from the data under the assumption that all other deviations from a constant water level were caused by recharge. The period of record for the recharge calculations was based on the time required for the waterlevel response to return to prerecharge levels; therefore, the period of record includes both the rise in water level associated with recharge and the dissipation of the water level. A specific yield of 0.15 was used on the basis of measurements made by Pool and Schmidt (1997). Bounding transmissivities of $1.6 \times 10^{-3}$ and $6.5 \times 10^{-3} \mathrm{~m}^{2} / \mathrm{s}$ estimated from Hanson and Benedict (1994) were used to show the uncertainty in the recharge values. The only difference between input data for the various sites was the individual water-level records and the distance of the well from the stream channel (to which the model showed little sensitivity in comparison with its sensitivity to transmissivity).
Recharge estimates were calculated for the sites near Dodge Boulevard, First Avenue, and La Cholla Boulevard for the recharge events of 1999 and 2000. The recharge event in 1999 was caused by summer streamflows, whereas the recharge event in 2000 was due predominantly to fall and winter streamflows and only partly to summer flows (table 1). The site near Craycroft Road was excluded from this analysis because the presence of vertical water-level gradients violated the assumptions of the analytical model. The largest cumulative recharge estimates for the 1999 event at the site near First Avenue range from $3.0 \times 10^{5}$ to $6.0 \times 10^{5} \mathrm{~m}^{3} / \mathrm{km}$, which is about two to three times larger than those from the other two sites (near Dodge Boulevard, $1.7 \times 10^{5}$ to $3.4 \times 10^{5} \mathrm{~m}^{3} / \mathrm{km}$; near La Cholla Boulevard, $1.3 \times 10^{5}$ to $2.5 \times 10^{5} \mathrm{~m}^{3} / \mathrm{km}$; table 2). Cumulative recharge estimates for the 2000 recharge event were greatest at the site near Dodge Boulevard and decreased in the downstream direction. At the site near Dodge Boulevard, recharge estimates range from $7.1 \times 10^{5}$ to $1.4 \times 10^{6} \mathrm{~m}^{3} / \mathrm{km}$, which are slightly larger than those estimated at the site near First Avenue $\left(5.3 \times 10^{5}\right.$ to $\left.1.1 \times 10^{6} \mathrm{~m}^{3} / \mathrm{km}\right)$ and about three times larger than those estimated at the site near La Cholla Boulevard $\left(2.2 \times 10^{5}\right.$ to $\left.4.3 \times 10^{5} \mathrm{~m}^{3} / \mathrm{km}\right)$. The recharge estimates for the 2000 event at the sites near First Avenue and near La Cholla Boulevard were about twice those for the 1999 event at these sites and were more than five times that of the 1999 event at the site near Dodge Boulevard. The trends revealed in this analysis are consistent with the fact that the winter 2000 streamflows were more voluminous and longer in duration than the summer 1999 streamflows (table 1), and that water levels in the piezometers rose higher in response to the winter 2000 streamflows than to the summer 1999 flows (fig. 21).

Volumetric recharge rates were estimated by dividing the cumulative-recharge estimates by the cumulative duration of streamflow at each site during the period of record. Streamflow duration at the streamflow-gaging station at Dodge Boulevard totaled about 9 days between July 1, 1999 and September 30, 1999, whereas streamflow duration at streamflow-gaging station 09486055, near La Cholla Boulevard, for the same period totaled about 4.5 days. No streamflow-gaging station existed near First Avenue; however, in this analysis, a total of about 7 days of cumulative flow was assumed to have occurred at the site near First Avenue during 1999_a duration less than that at the upstream gage, at Dodge Boulevard, and greater than that at the downstream gage, near La Cholla Boulevard. Using the values of estimated cumulative-recharge determined using the Moench and Kisiel (1970) method and of cumulative-streamflow duration, recharge rates range from 0.2 to $1.0 \mathrm{~m}^{3} / \mathrm{s} / \mathrm{km}$ for 1999 (table 2). During the period of June 15 to December 31, 2000, a span that includes most of the streamflow for the second recharge period, cumulative-streamflow duration ranged from a high of 43 days at the streamflow-gaging station at Dodge Boulevard, to a low of 14 days at the streamflow-gaging station near La Cholla Boulevard. In this analysis, a flow duration of 30 days was assumed to have occurred at the site near First Avenue. Using these values, volumetric-recharge rates range from 0.2 to $0.4 \mathrm{~m}^{3} / \mathrm{s} / \mathrm{km}$ for 2000 (table 2). These rates are generally greater than volumetric-infiltration estimates 

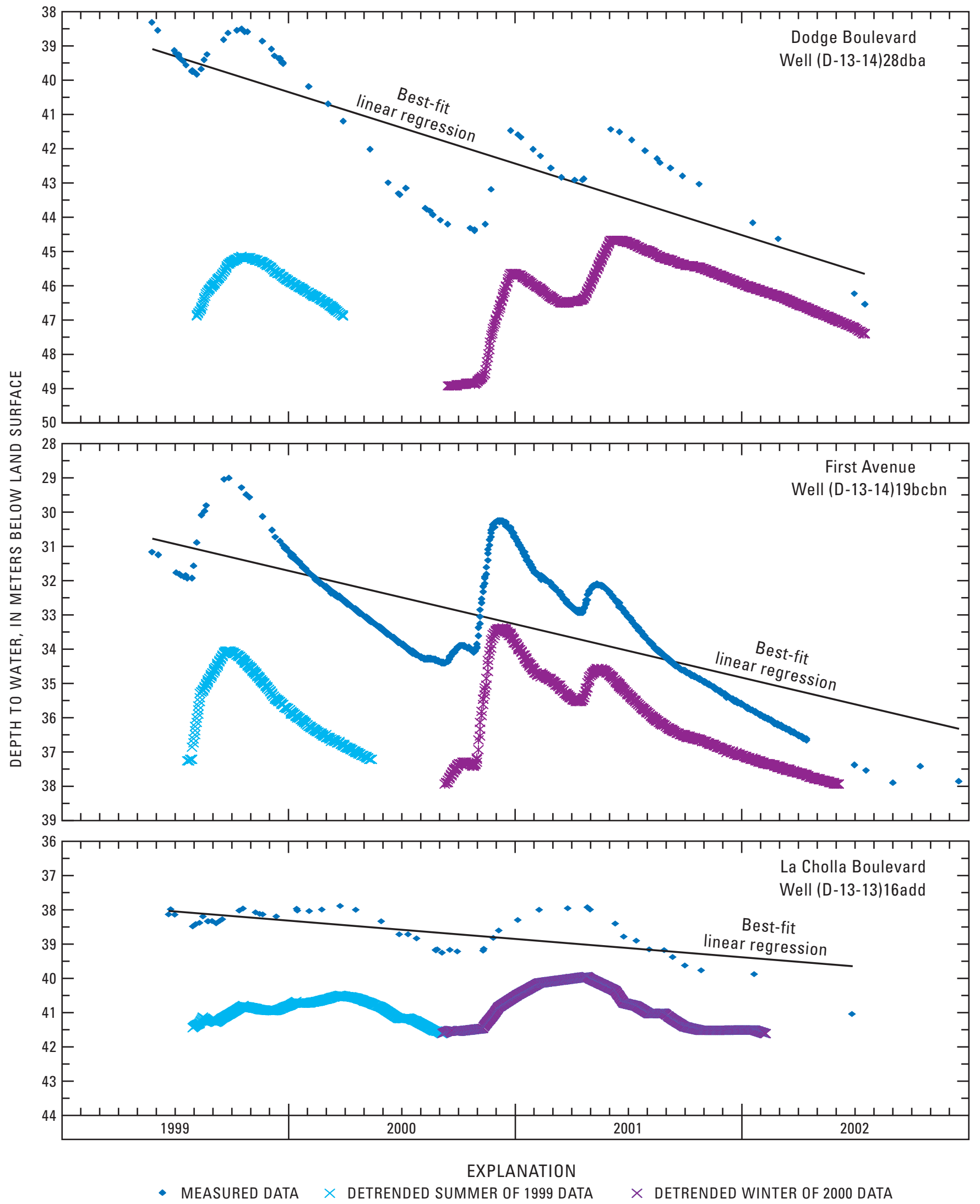

Figure 22. Measured and detrended hydrographs of selected piezometers within Rillito Creek, Pima County, Arizona. 
Table 2. Recharge estimates for sites in Rillito Creek, Pima County, Arizona, using the Moench and Kisiel (1970) analytical-model method. $\left[\mathrm{m}^{2} / \mathrm{sec}\right.$, square meters per second; $\mathrm{m}^{3} / \mathrm{km}$, cubic meters per kilometer; $\mathrm{m}^{3} / \mathrm{s} / \mathrm{km}$, cubic meters per second per kilometer]

\begin{tabular}{|c|c|c|c|c|c|c|}
\hline Site location & $\begin{array}{l}\text { Distance of well } \\
\text { from center of Ril- } \\
\text { lito Creek channel, } \\
\text { in meters }\end{array}$ & Recharge & \multicolumn{2}{|c|}{1999} & \multicolumn{2}{|c|}{2000} \\
\hline \multirow[t]{2}{*}{ Dodge Boulevard } & 3 & $\begin{array}{l}\text { Length of recharge } \\
\text { period, in days }{ }^{1}\end{array}$ & \multicolumn{2}{|c|}{9} & \multicolumn{2}{|c|}{43} \\
\hline & & Total, in $\mathrm{m}^{3} / \mathrm{km}$ & $1.7 \times 10^{5}$ & $3.4 \times 10^{5}$ & $7.1 \times 10^{5}$ & $1.4 \times 10^{6}$ \\
\hline \multirow[t]{3}{*}{ First Avenue } & 45.7 & $\begin{array}{l}\text { Length of recharge } \\
\text { period, in days }{ }^{1}\end{array}$ & \multicolumn{2}{|c|}{7} & \multicolumn{2}{|c|}{30} \\
\hline & & Total, in $\mathrm{m}^{3} / \mathrm{km}$ & $3.0 \times 10^{5}$ & $6.0 \times 10^{5}$ & $5.3 \times 10^{5}$ & $1.1 \times 10^{6}$ \\
\hline & & Rate, in $\mathrm{m}^{3} / \mathrm{s} / \mathrm{km}$ & 0.5 & 1 & 0.2 & 0.4 \\
\hline $\begin{array}{l}\text { La Cholla } \\
\text { Boulevard }\end{array}$ & & Rate, in $\mathrm{m}^{3} / \mathrm{s} / \mathrm{km}$ & 0.3 & 0.7 & 0.2 & 0.4 \\
\hline
\end{tabular}

${ }^{1}$ Refers to the cumulative time streamflow existed in Rillito Creek. Streamflow durations were calculated using data from the streamflow-gaging stations near Dodge and La Cholla Boulevards.

made using temperature, water-content, and seepage-loss methods. Because infiltrated water can be stored in the shallow subsurface it is available for subsequent evaporation and (or) transpiration; therefore, infiltration rates typically provide an upper bound for recharge rates. Estimated recharge rates in excess of infiltration rates indicate unaccounted sources of water. These unaccounted sources likely are inputs from adjacent tributaries, many of which drain the pediment north of Rillito Creek.

\section{Temporal Gravity Measurements}

Ground-water storage was monitored along two gravity profiles across Rillito Creek at Swan Road (5-km length) and First Avenue (6.4-km length). The profiles included 11 gravity stations that are closely spaced near Rillito Creek and at wells where water levels are monitored (fig. 1). Gravity changes along both profiles after summer 1999 show that increases in ground-water storage were primarily within the flood plain coincident with the stream alluvium (fig. 23). Gravity increases on the First Avenue profile were largest between these measurement dateswere at the station nearest Rillito Creek. The largest increase between June 199 and August 1999 was 48 microgals, which is equivalent to about $1.1 \mathrm{~m}$ of water, assuming the mass change occurs within a horizontal slab of infinite extent. Gravity increase on the Swan Road profile also was largest between the June 1999 and August 1999 measurements at the station about $0.5 \mathrm{~km}$ south of Rillito Creek. The greatest change between these measurement dates was 42 microgals (equivalent to about $1 \mathrm{~m}$ of water). The gravity changes and associated water-level rises indicate that the highly permeable stream-channel and flood-plain deposits act as a ground-water reservoir that readily accepts infiltrated streamflow.

Estimates of recharge through infiltration along Rillito Creek were made by assuming the storage changes measured by gravity at each profile were equivalent to recharge and by integrating the two-dimensional gravity change for the length of the creek. Similar to that shown with water-level trends, the overall storage-change estimates during the period of study steadily declined with two periods of recharge superimposed on the longer-term rate of decline (fig. 24). The long-term storage decline shown in figure 24 is related to the dissipation of a water-table mound produced in 1998, from sustained flows related to the El Niño precipitation, and to ground-water pumpage from nearby public and private wells. The periods of increased storage that reduce the rate of longterm declines were associated with the summer 1999 and fall/winter 2000 streamflows (figs. 3 and 24). The increase in storage for the summer 1999 period is about $7.5 \times 10^{6} \mathrm{~m}^{3}$; for the fall/winter 2000-2001 period it is about $11.1 \times 10^{6} \mathrm{~m}^{3}$ for the 14-km reach between Craycroft Road and La Cholla Boulevard. Although measurable, these seasonal storage increases are small compared to the storage increases associated with the 1998 El Niño event, which were about $5 \times 10^{7}$ $\mathrm{m}^{3}$ (fig. 24).

Assuming that the increases in storage measured in summer 1999 and fall/winter 2000-2001 were uniform throughout the 14-km reach between Craycroft Road and La Cholla Boulevard, they would equate to $5 \times 10^{5} \mathrm{~m}^{3} / \mathrm{km}$ and 
A. Swan Road profile

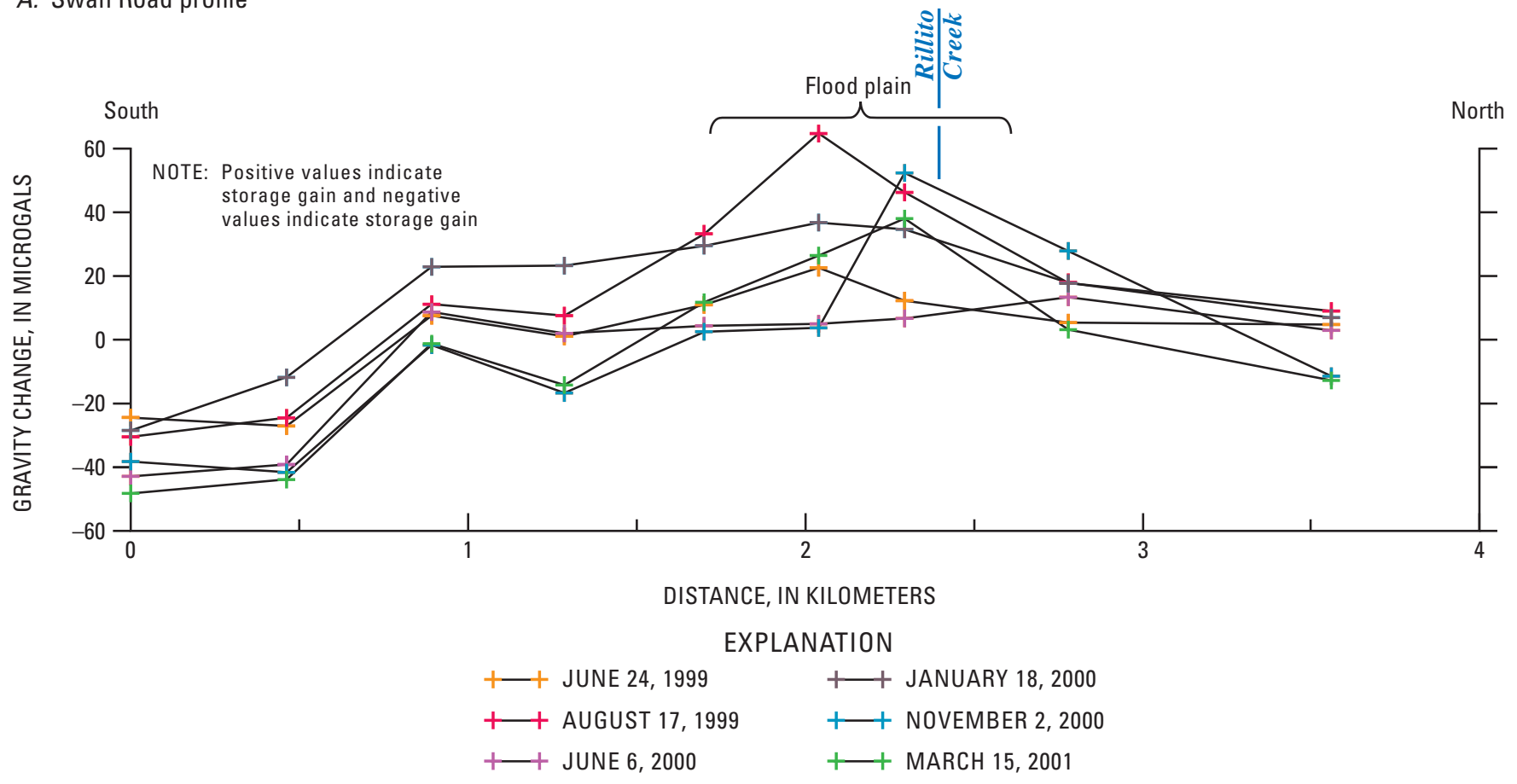

B. First Avenue profile

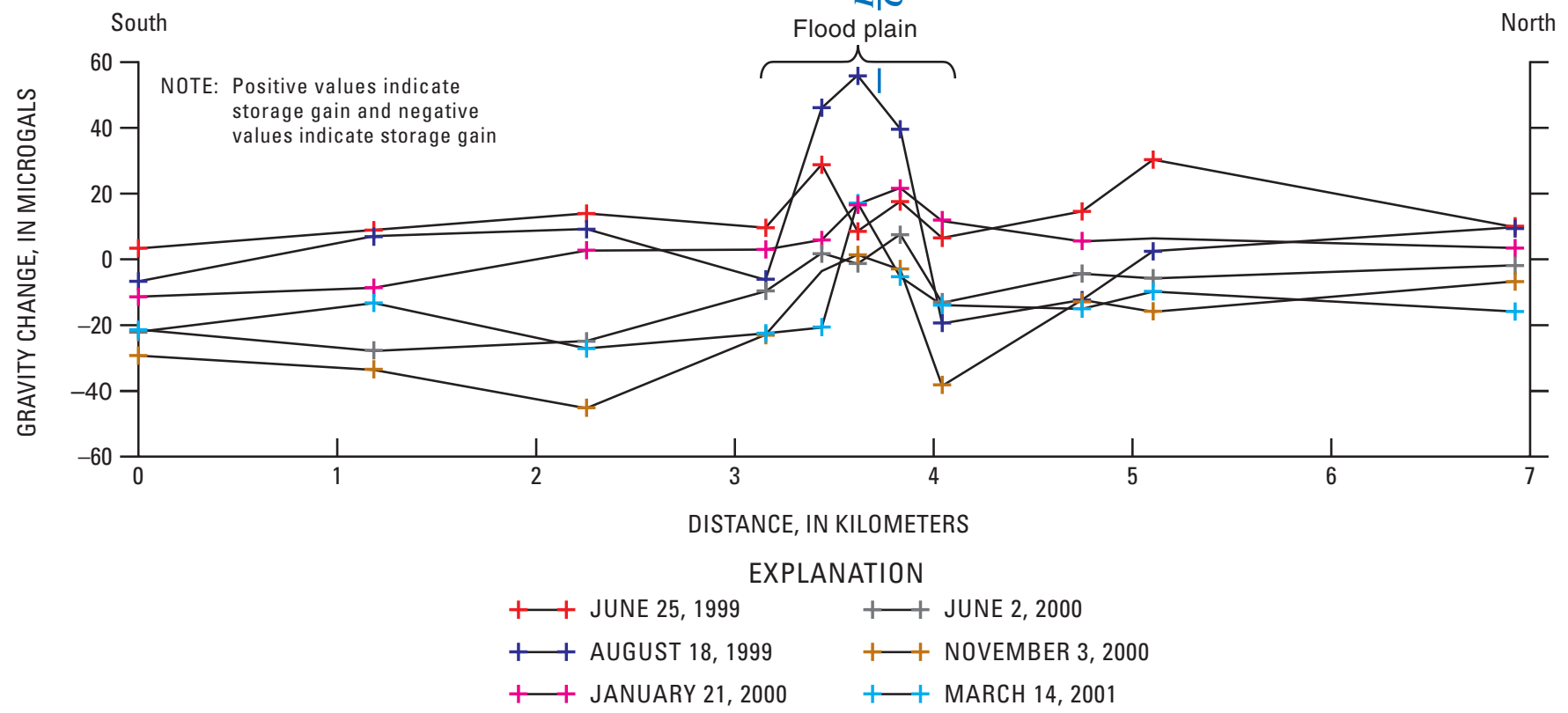

Figure 23. Gravity changes along profiles crossing Rillito Creek, Pima County, Arizona, since December 1997. A, Swan Road; $B$, First Avenue. 
$8 \times 10^{5} \mathrm{~m}^{3} / \mathrm{km}$, respectively. Using 7 days of flow (as estimated at First Avenue; table 2) for the summer 1999 event and 30 days of flow for the fall/winter 2000-2001 event, these recharge volumes equate to $0.9 \mathrm{~m}^{3} / \mathrm{s} / \mathrm{km}$ in the 1999 event, and $0.3 \mathrm{~m}^{3} / \mathrm{s} /$ $\mathrm{km}$ in the 2000-2001 event.

These rates are generally similar to those estimated using water-level methods, yet greater than volumetric-infiltration estimates made using temperature, water-content, and seepage-loss methods. As discussed previously, recharge-rate estimates in excess of infiltration-rate estimates indicate unaccounted sources of water. These unaccounted sources likely are inputs from adjacent tributaries, many of which drain the mountain-front area north of Rillito Creek.

Two-dimensional simulations of the change in water distribution in the subsurface required to produce the change in gravity for the period June 24, 1999 to August 18, 1999, along both profiles are shown in figure 25. Simulations used GM-SYS software (version 4.6) developed by Northwest Geophysical Associates, Inc. The software calculates the gravity field response of polygonal features of variable subsurface density using the theory and algorithms of Talwani and others (1959), and Won and Bevis (1987). Simulation of the two-dimensional vertical polygons requires simplifying assumptions about the distribution of storage change in the third dimension, in this case along the stream channel, and at the margin of the simulated region. This application assumed the two-dimensional polygons of storage change extended in infinite length along the stream channel. Storage change in the crystalline rocks adjacent to the northern boundary of the aquifer was assumed to be insignificant. Storage change in the aquifer adjacent to the southern end of the profiles was assumed to extend laterally to an infinite distance. Each of these assumptions likely contributes little to no errors in the simulation. Available water-level data and gravity-derived estimates of specific yield were used to constrain the vertical distribution of saturated storage change at many gravity-station wells. Gravity changes along the First Avenue profile are explained by a combination of higher water levels and increases in water content in the unsaturated zone. A 10 -percent increase in unsaturated water content was required to match the observed gravity change at gravity stations near the channel. The resulting model (fig. 25A) resulted in simulation errors of less than 1 microgal at each station.

Simulation of gravity change along the Swan Road profile could be explained by storage change within the zone of water-level change: no changes in water content in the unsaturated zone were required. Increases in gravity at all stations along the Swan Road profile during June 24, 1999, to August 17, 1999, (fig. 25B) indicated that infiltration and recharge during the intervening period between gravity surveys resulted in storage increases within about $2 \mathrm{~km}$ of the stream channel. The greatest increases in gravity occurred at the two stations within about $0.5 \mathrm{~km}$ south of the channel. Gravity increases at stations farther from the channel ranged from 2 to 23 microgal. The resulting model (fig. 25B) resulted in simulation errors of generally less than 1 microgal at each station.

\section{Summary and Conclusions}

The amount of water currently recharging the aquifers within the Tucson area is insufficient to meet current and future demands. Resultant ground-water deficits are manifested in water-level declines of more than $60 \mathrm{~m}$ since the middle of the twentieth century. The accurate determination of recharge is critical to establishing a sustainable water budget on the basin scale. In semiarid regions, recharge beneath ephemeral-stream

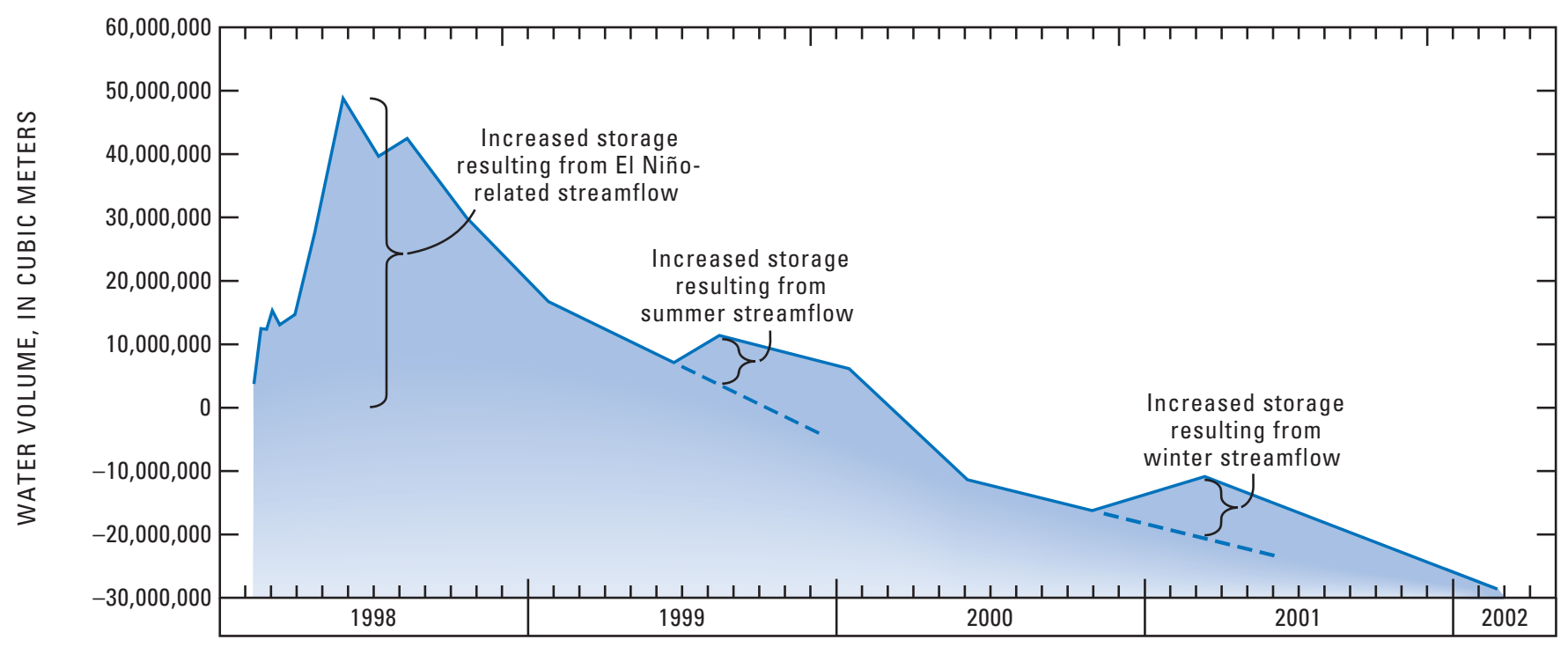

Figure 24. Storage changes measured along Rillito Creek, Pima County, Arizona, from Craycroft Road to La Cholla Boulevard relative to a measurement made in December 1997. 
channels typically represents a major component of the total recharge. Improved understanding of streambed infiltration and the subsequent redistribution of water within the unsaturated zone is fundamental to quantifying and forming an accurate description of streambed recharge.

One of the challenges of quantitatively studying recharge beneath ephemeral-stream channels is the need to integrate measurements made over a wide range of spatial and temporal scales. No single method of measurement or analysis can resolve the complex physical processes that contribute to infiltration, percolation, and recharge beneath these channels; therefore, various approaches that provide a wide range of temporal and spatial scale measurements of recharge beneath Rillito Creek were used in this study. The approaches discussed in this chapter included analyses of cores and cuttings for hydraulic and textural properties, environmental tracers from the water extracted from the cores and cuttings, seepage measurements made during sustained streamflow, heat as a tracer and numerical simulations of the movement of heat through the streambed sediments, water-content variations within a two-dimensional array, water-level responses to streamflow in piezometers within the stream channel, and gravity changes in response to recharge.
The amount of water flowing in Rillito Creek, and therefore the amount available for ground-water recharge, is primarily related to precipitation frequency, distribution, and intensity, as well as to streamflow and basin/channel runoff characteristics. The temporal distribution of flow in ephemeral streams is highly varied. Because of this, estimating or predicting recharge rates for ephemeral-stream channels on the basis of limited temporal observations is particularly difficult. This investigation extended from 1999 through most of 2002 and represented a time of lower than average precipitation and streamflow on the basis of data from the previous 30 years. Estimates of cumulative infiltration and recharge during this study period may differ from long-term averages; however, estimates of infiltration and recharge rates for streamflow events during the study period can be extrapolated to a variety of climatic conditions.

In order for ephemeral streamflow within Rillito Creek to recharge the underlying aquifer, the water must first infiltrate into the stream-channel deposits and percolate downward through the underlying deposits. The ability of water to infiltrate and percolate through these deposits is a function of the availability of streamflow and the hydraulic properties of the deposits. Study results indicate that the ver-
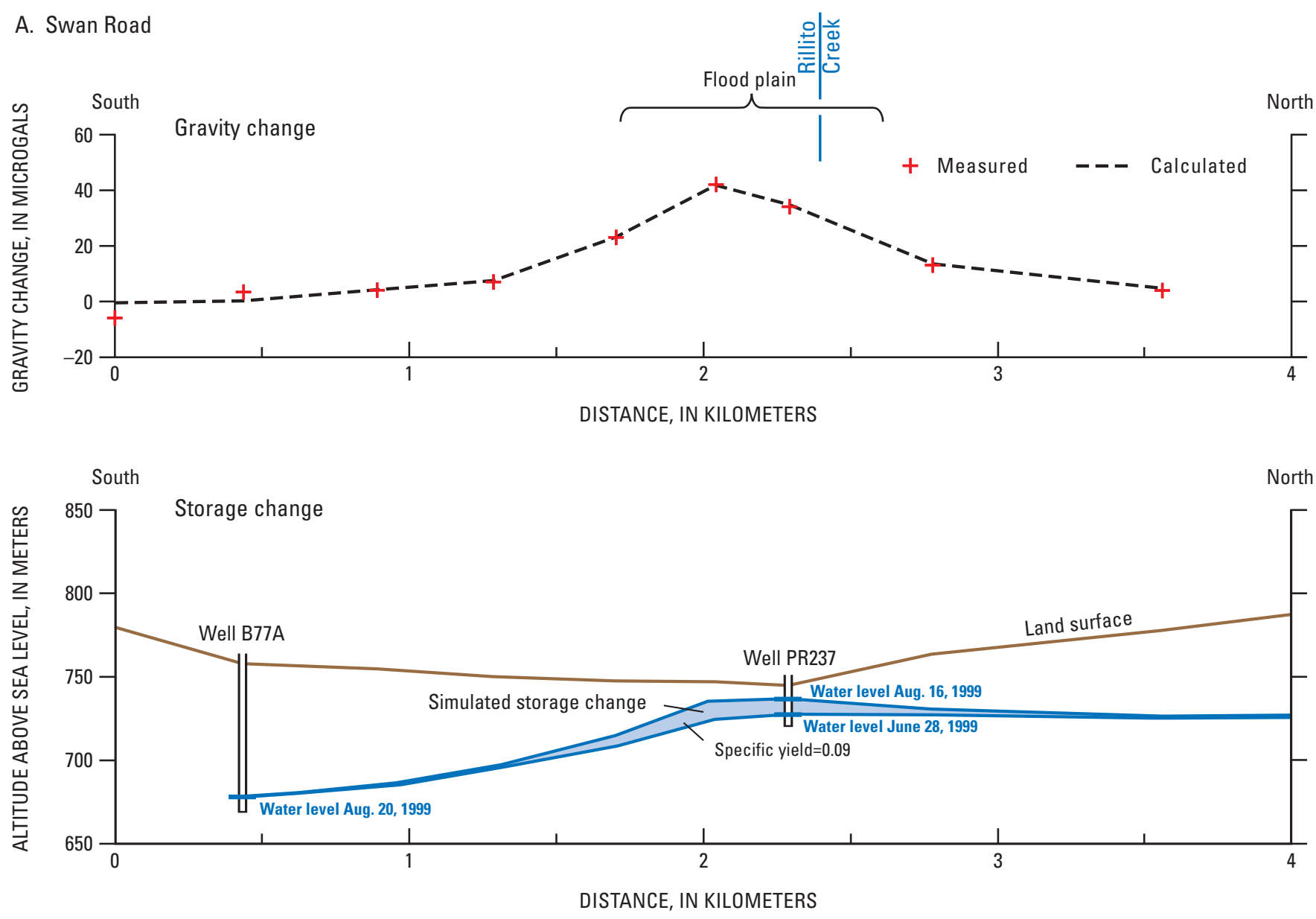

Figure 25. Gravity-model results for profiles crossing Rillito Creek, Pima County, Arizona. $A$, Swan Road; $B$, First Avenue. 
B. First Avenue
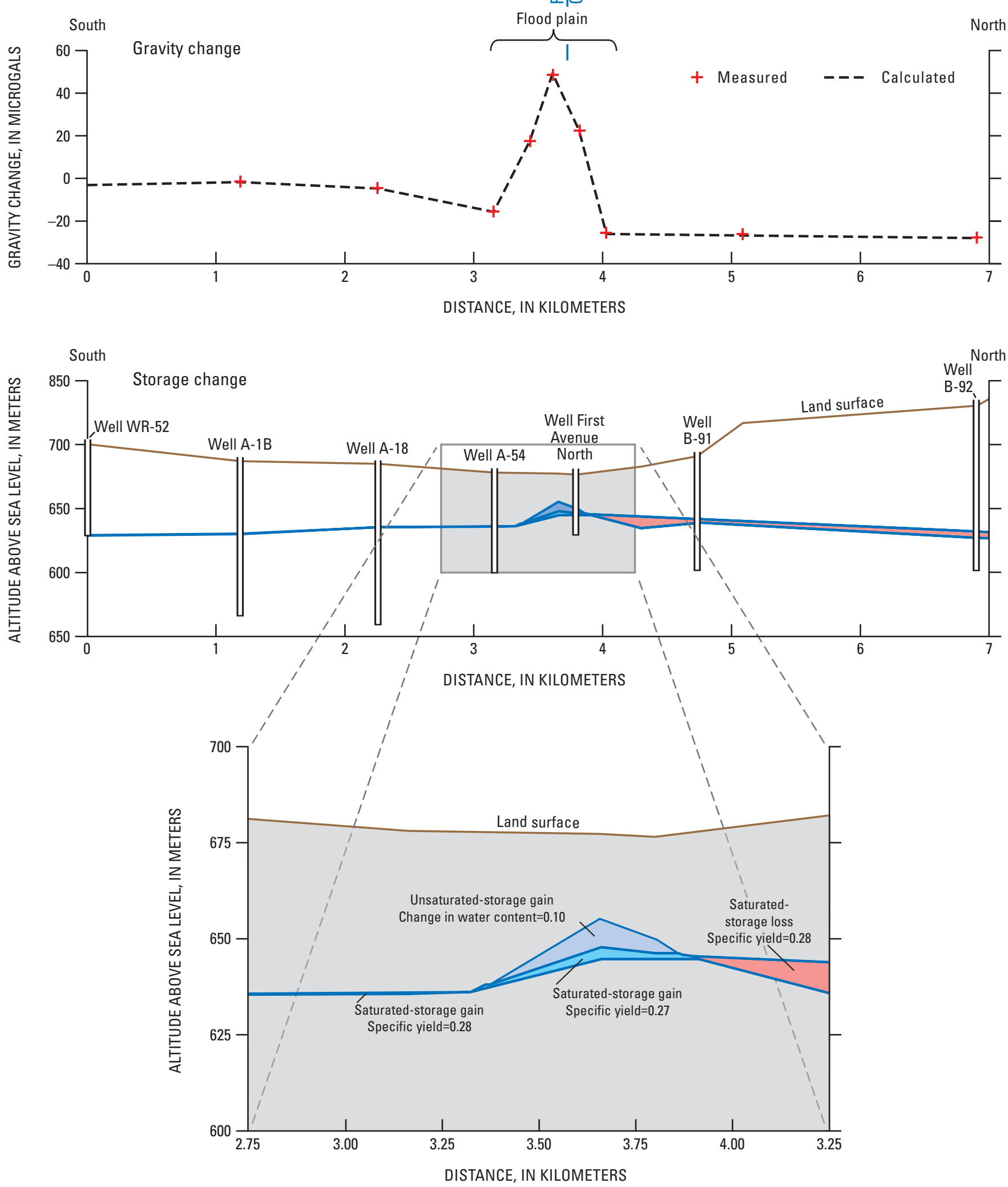

Figure 25.-Continued. 
tical hydraulic conductivity of the stream-channel deposits ranges from 0.3 to $2.5 \mathrm{~m} / \mathrm{d}$, whereas hydraulic conductivity of the the basin-fill deposits ranges from 0.012 to 0.61 $\mathrm{m} / \mathrm{d}$. For heterogeneous media, such as the deposits beneath Rillito Creek, the equivalent vertical hydraulic conductivity is calculated as the harmonic mean of the Ksat for each textural layer within the deposits. Although differing at each borehole, the overall average equivalent saturated hydraulic conductivity of the stream-channel deposits is $1.2 \mathrm{~m} / \mathrm{d}$; the overall average equivalent saturated hydraulic conductivity of the basin-fill deposits is $0.19 \mathrm{~m} / \mathrm{d}$; and the equivalent hydraulic conductivity of the stream-channel and basin-fill deposits together is about $0.23 \mathrm{~m} / \mathrm{d}$ (table 3 ). Assuming no preferential flow occurs and unit gradient conditions, these equivalent vertical hydraulic conductivity values provide an estimate of long-term potential recharge rates under saturated conditions. To convert these values into potential recharge volumes, assumptions of flow duration and average wetted perimeter and length must be made. For example, using an annual cumulative flow duration of 36 days per year for Rillito Creek, an average wetted perimeter of $20 \mathrm{~m}$ and a wetted length of $20 \mathrm{~km}$, yields an annual volumetric recharge of $4.3 \times 10^{6} \mathrm{~m}^{3} / \mathrm{y}$, which is about two-thirds of the commonly reported long-term average recharge of $6 \times 10^{6} \mathrm{~m}^{3} / \mathrm{y}$ (Hanson and Benedict, 1994).

Environmental tracers were used to evaluate spatial variations in infiltration and recharge patterns along Rillito Creek and estimate percolation rates through the unsaturated zone. Tritium was detected in pore water extracted from all core samples and ranged from 2 to $11 \mathrm{TU}$, indicating that water in the unsaturated zone infiltrated during the past 40 years. Given the presence of tritium in the unsaturated zone, the locally high vertical hydraulic conductivity values greater than $1 \mathrm{~m} / \mathrm{d}$ in the stream-channel deposits, and a depth to the water table of generally less than $40 \mathrm{~m}$, it is likely that most of the pore water extracted from the cores infiltrated during runoff events in the past few years. Variations in isotopic compositions of ground water beneath Rillito Creek are attributed to changes in the compositions of the source water and to evaporation. The lack of an evaporative signal for some samples indicates that percolating water was exposed to minimal evaporation.

Isotopic ratios measured in the pore water during the study are representative of the isotopic ratios in the infiltrating waters of the recent past. Isotopic ratios in Rillito Creek pore water become lighter in the downstream direction indicating that for the time period represented by the unsaturated-zone pore water, the longer duration and isotopically lighter winter storms were more important contributors to infiltration in the downstream reaches than in the upstream reaches. The trends in isotopic ratios measured in the pore-water cores approximately match the trends in ratios in the basin precipitation from particular storms during the year prior to drilling. Correlation between the precipitation events and depths of infiltration, on the basis of corresponding isotopic signatures, indicates an average vertical- percolation rate of approximately $0.049 \mathrm{~m} / \mathrm{d}$ at the Dodge Boulevard borehole site (table 3). Chloride concentrations in pore-water leachate determined from drill cuttings varied substantially through the upper $18 \mathrm{~m}$ at all sites. Below about $18 \mathrm{~m}$, variation in chloride concentration declined considerably. This zone of smaller variation is interpreted as corresponding to the infiltration depth of the 1998 El Niño water. The low variability and low mean value of chloride concentration is attributed to a constant supply of runoff having a low chloride concentration. In addition, the low chloride concentration indicates the water had little exposure to evaporation. The higher variability and concentration observed in post-El Niño pore water above $18 \mathrm{~m}$ likely is due to mobilization of chloride from evaporative concentrates and dry fallout deposited between precipitation events that resulted in runoff along a variety of surface-water flow paths. Calculation of a downward percolation rate using the El Niño event marker in the chloride profile yields an average percolation rate of $0.055 \mathrm{~m} / \mathrm{d}$ (table 3 ). Although the estimates of recharge determined by hydraulic properties and environmental tracers required the assumption of no preferential flow, the water-level responses measured in the deep piezometers indicate that factors such as preferential flow likely influence recharge rates. Estimates made using these techniques, therefore, are likely representative of minimum values.

Infiltration rates are typically assumed to provide an upper bound for recharge rates. Infiltration rates were estimated using seepage-loss, temperature, and water-content methods. Seepage measurements made at several sites along Rillito Creek during the El Niño-related sustained flows of March through April 1998 and again on October 24, 2000, indicate that streamflow losses owing to infiltration along Rillito Creek ranged from 0.07 to $0.9 \mathrm{~m}^{3} / \mathrm{s} / \mathrm{km}$ and averaged $0.21 \mathrm{~m}^{3} / \mathrm{s} / \mathrm{km}$ (table 3). Streamflow losses were smallest in the upstream reaches. The losses in these reaches were attributed to a shallow water table and rejected recharge. Using a wetted perimeter of $25 \mathrm{~m}$, which was the average width of the flow that occurred during October 2000, the calculated average infiltration rate is $0.7 \mathrm{~m} / \mathrm{d}$, (table 3 ) which is similar to the measured saturated hydraulic conductivity of the stream-channel deposits but more than an order of magnitude greater than percolation rates determined by tracers. The difference between the estimated infiltration and percolation rates probably is due to the variably saturated nature of the sediments. The near-surface stream-channel deposits are likely to be nearly saturated during streamflow and therefore are approaching their saturated hydraulic conductivity, whereas the deeper sediments are less saturated and will therefore have a lower hydraulic conductivity.

Infiltration-rate estimates made using temperature and water-content methods in this study are one dimensional; information on stream width and length are required to estimate volumetric rates from the infiltration estimates. Model simulations using streambed-temperature data indicate the likelihood of a thin surface layer having a low vertical 
hydraulic conductivity at the site near Craycroft Road. The addition of this surface layer to the model domain resulted in a lowering of the simulated equivalent saturated hydraulic conductivity by four orders of magnitude from about $4 \mathrm{~m} / \mathrm{d}$ to $3 \times 10^{-4} \mathrm{~m} / \mathrm{d}$. The four orders of magnitude change is too large to result solely from changes in water viscosity owing to temperature changes. Given the tranquil flow conditions during the first modeled flow period near Craycroft Road, it is possible that the change resulted from the deposition of a fine-grained layer of sediment on the streambed surface. In fact, a thin layer of fine-grained material commonly was observed at the sites after small streamflows. Vertical hydraulic gradients measured in the nested piezometers at the site near Craycroft Road allowed for estimation of infiltration rates using simulated equivalent vertical saturated hydraulic conductivity. Vertical hydraulic gradients during and shortly after streamflow were typically $0.1 \mathrm{~m} / \mathrm{m}$. Estimated infiltration rates ranged from $0.09 \mathrm{~m}^{3} / \mathrm{s} / \mathrm{km}$ during the period probably most representative of ephemeralstreamflow conditions. The infiltration rate of $0.09 \mathrm{~m}^{3} / \mathrm{s} /$ $\mathrm{km}$ (table 3 ) is about half of that estimated using seepagemeasurement data. The difference between these methods is primarily the wetted-perimeter value used in the calculation. The seepage-measurement estimates used a wetted perimeter of $25 \mathrm{~m}$ that was based on measured stream width, whereas a wetted perimeter of $10 \mathrm{~m}$ was used for flows during the period modeled with the temperature method because flows during this period were smaller than those during the seepage measurements. If hydraulic conductivity and vertical gradient are assumed not to change with increasing wetted perimeter and these rates are extrapolated to a wetted perimeter of 25 $\mathrm{m}$, infiltration rates estimated with the temperature method are $0.23 \mathrm{~m}^{3} / \mathrm{s} / \mathrm{km}$ - virtually the same that measured by the seepage-loss method.

Two-dimensional arrays of temperature and watercontent sensors indicated that water-content measurements enable better estimates of rapid-infiltration rates associated with the onset of streamflow. Infiltration rates within the first few minutes after the onset of streamflow were as large as $166 \mathrm{~m} / \mathrm{d}$; however, saturation within the relatively homogeneous stream-channel deposits of Rillito Creek was established in less than 10 minutes and subsequent infiltration rates declined significantly. Simplified one-dimensional model simulations used to estimate infiltration as soon as the sediments were saturated indicate infiltration rates declined as streamflow duration increased and averaged $0.32 \mathrm{~m} / \mathrm{d}$ for the 12-day event in April 2000 and $0.37 \mathrm{~m} / \mathrm{d}$ for the 10-day event in November (table 3 ). The declining infiltration rate is attributed to a declining pressure head and (or) development of a thin fine-grained surface layer. On the basis of a wetted perimeter of $10 \mathrm{~m}$, an average infiltration rate of $0.32 \mathrm{~m} / \mathrm{d}$ equates to a flux of $0.04 \mathrm{~m}^{3} / \mathrm{s} / \mathrm{km}$ (table 3 ).

Water levels in the stream-channel piezometers showed an overall decline during the period of investigation in relation to long-term records. The water-level decline probably is related to ground-water pumpage from the basin-fill deposits. Superimposed on the water-level decline is a series of waterlevel rises that range from about 0.5 to $3.9 \mathrm{~m}$. These rises were in response to the two periods of greatest streamflow occurring in the summer of 1999 and the fall/winter of 2000. The water-level responses to streamflow were followed by gradual water-level dissipation.

Water-level responses were analyzed by using an analytical model to simulate cumulative recharge for the water-level rises measured in 1999 and 2000. The largest cumulative-recharge estimates for the 1999 event were for a piezometer site near the middle of the study reach and range from $3.0 \times 10^{5}$ to $6.0 \times 10^{5}$ $\mathrm{m}^{3} / \mathrm{km}$. This range is about two to three times as large as that for the other two sites. Estimates of recharge for 2000 were about two- to five-times that of the estimates for 1999. The trends revealed in this analysis are consistent with streamflow volumes and duration, and the magnitude of water-level changes that occurred in the piezometers in response to the streamflow. Cumulative-recharge estimates for the 2000 recharge event were greatest at the upstream-most site and decreased in the downstream direction. Recharge estimates for the upstream-most site range from $7.1 \times 10^{5}$ to $1.4 \times 10^{6} \mathrm{~m}^{3} / \mathrm{km}$; these values are slightly larger than those estimated for the middle-reach site and about three times greater than that estimated for the site farthest downstream. Recharge rates, estimated by dividing the cumulativerecharge estimates by the cumulative duration of streamflow, resulted in rates that range from 0.2 to $1.0 \mathrm{~m}^{3} / \mathrm{s} / \mathrm{km}$ for 1999 and from 0.2 to $0.4 \mathrm{~m}^{3} / \mathrm{s} / \mathrm{km}$ for 2000 (table 3 ).

Gravity methods used to estimate recharge through infiltration along Rillito Creek provide values similar to those made by using the water-level method. Both gravity- and water level-derived estimates, however, are higher than the infiltration-rate estimates made by using seepage, temperature, or water-content change methods. Typically, infiltrationrate estimates provide an upper bound for recharge-rate estimates as some of the infiltrated water is stored in the shallow subsurface and used by vegetation, or is subsequently evaporated. The relatively high estimates of recharge determined by the gravity and water-level methods compared to estimates of infiltration determined by use of the seepage, temperature, and water-content methods probably is due to recharge from ungaged tributaries. The ungaged tributaries provide additional wetted perimeter and channel length not accounted for in the recharge estimates made by using the seepage, temperature, and water-content methods. 
Table 3. Summary of methods used and estimated rates of infiltration, percolation, and recharge along Rillito Creek, Pima County, Tucson, Arizona.

[m/d, meters per day; $\mathrm{m}^{3} / \mathrm{s}$, cubic meters per second; $\mathrm{m}^{3} / \mathrm{yr}$, cubic meters per year]

\begin{tabular}{|c|c|c|c|c|c|}
\hline Method & $\begin{array}{l}\text { One-dimensional } \\
\text { infiltration rate, } \\
\mathrm{m} / \mathrm{d}\end{array}$ & $\begin{array}{l}\text { Vertical } \\
\text { percola- } \\
\text { tion rate, } \\
\text { m/d }\end{array}$ & $\begin{array}{l}\text { Volumetric } \\
\text { rate, m³/s per } \\
\text { kilometer of } \\
\text { streamflow } \\
\text { (wetted } \\
\text { perimeter } \\
\text { of } 25 \text { meters } \\
\text { is used for } \\
\text { temperature- } \\
\text { method } \\
\text { estimates) }\end{array}$ & $\begin{array}{c}\text { Potential } \\
\text { annual } \\
\text { average } \\
\text { recharge; } \\
\text { assumes } \\
36 \text { days of } \\
\text { flow in the } \\
20 \text { kilome- } \\
\text { ter reach, } \\
\text { m }^{3} / y r\end{array}$ & Comments \\
\hline $\begin{array}{l}\text { Physical: equiva- } \\
\text { lent saturated } \\
\text { hydraulic } \\
\text { conductivity }\end{array}$ & 0.23 & $\begin{array}{l}\text { Not } \\
\text { calculated }\end{array}$ & $\begin{array}{l}\text { Not } \\
\text { calculated }\end{array}$ & $4.1 \times 10^{6}$ & $\begin{array}{l}\text { From Darcy's Law the flow rate through the sediments } \\
\text { under saturated conditions is equal to the product of } \\
\text { the hydraulic conductivity and the hydraulic gradient. } \\
\text { This method uses the average vertical equivalent satu- } \\
\text { rated hydraulic conductivity of the combined stream- } \\
\text { channel and basin-fill deposits multiplied by a unit } \\
\text { gradient to estimate a recharge rate in meters per day. }\end{array}$ \\
\hline $\begin{array}{l}\text { Stable-isotope } \\
\text { profiles }\end{array}$ & $\begin{array}{l}\text { Not } \\
\text { calculated }\end{array}$ & 0.049 & $\begin{array}{l}\text { Not } \\
\text { calculated }\end{array}$ & $\begin{array}{l}\text { Not } \\
\text { calculated }\end{array}$ & $\begin{array}{l}\text { Method uses isotopic signatures associated with specific } \\
\text { streamflow events and correlates pore water at depth } \\
\text { with timing of introduction of water to unsaturated } \\
\text { zone. }\end{array}$ \\
\hline Chloride profiles & $\begin{array}{l}\text { Not } \\
\text { calculated }\end{array}$ & 0.055 & $\begin{array}{l}\text { Not } \\
\text { calculated }\end{array}$ & $\begin{array}{l}\text { Not } \\
\text { calculated }\end{array}$ & $\begin{array}{l}\text { Method uses chloride concentrations associated with } \\
\text { streamflow seasons and correlates pore water at } \\
\text { depth with season (timing) water was introduced to } \\
\text { unsaturated zone. }\end{array}$ \\
\hline Seepage losses & 0.75 & $\begin{array}{l}\text { Not } \\
\text { calculated }\end{array}$ & $\begin{array}{l}0.07 \text { to } 0.9 \\
\text { average of } \\
0.21\end{array}$ & $13.7 \times 10^{6}$ & $\begin{array}{l}\text { Method uses differences in streamflow measurements to } \\
\text { calculate streamflow losses. Seepage losses represent } \\
\text { infiltration rates in cubic meters per kilometer per } \\
\text { second of streamflow. The one-dimensional rate } \\
\text { ( } 0.75 \text { meter per day) was calculated by using the } \\
\text { average ( } 0.21 \text { cubic meters per kilometer per second). }\end{array}$ \\
\hline $\begin{array}{l}\text { Temperature data } \\
\text { from two-dimen- } \\
\text { sional trench }\end{array}$ & $\begin{array}{l}0.32 \text { (April 2000) } \\
0.37 \text { (November } \\
2001)\end{array}$ & $\begin{array}{l}\text { Not } \\
\text { calculated }\end{array}$ & 0.09 & $5.8 \times 10^{6}$ & $\begin{array}{l}\text { Temperature modeling results in vertical infiltration } \\
\text { rates of } 0.32 \text { to } 0.37 \text { meters per day; drainage-rate } \\
\text { measurements after cessation of streamflow result in } \\
\text { a vertical velocity of } 0.46 \text { meters per day. }\end{array}$ \\
\hline Water level & Not calculated & $\begin{array}{l}\text { Not } \\
\text { calculated }\end{array}$ & $\begin{array}{l}0.2 \text { to } 1.0 \text { for } \\
1999 \\
0.2 \text { to } 0.4 \text { for } \\
2000-2001\end{array}$ & $\begin{array}{l}\text { Not } \\
\text { calculated }\end{array}$ & $\begin{array}{l}\text { Method uses an analytical solution to simulate recharge } \\
\text { on the basis of a hydrograph response. Volumet- } \\
\text { ric rates represent recharge rates for the period of } \\
\text { streamflow in respective years. }\end{array}$ \\
\hline $\begin{array}{l}\text { Gravity integrated } \\
\text { from Craycroft } \\
\text { Road to } \\
\text { La Cholla } \\
\text { Boulevard }\end{array}$ & Not calculated & $\begin{array}{l}\text { Not } \\
\text { calculated }\end{array}$ & $\begin{array}{l}0.8 \text { for } 1999 \\
0.3 \text { for } \\
\quad 2000-2001\end{array}$ & $\begin{array}{l}\text { Not } \\
\text { calculated }\end{array}$ & $\begin{array}{l}\text { Method uses ground-water storage changes measured at } \\
\text { Swan Road and First Avenue, and extents the storage } \\
\text { changes upstream to Craycroft Road and downstream } \\
\text { to La Cholla Boulevard. An average flow duration } \\
\text { listed in table } 2 \text { is used to estimate the rate. }\end{array}$ \\
\hline
\end{tabular}




\section{References Cited}

Anderson, S.R., 1987, Cenozoic stratigraphy and geologic history of the Tucson basin, Pima County, Arizona: U.S. Geological Survey Water-Resources Investigations Report 87-4190, 20 p.

Anderson, S.R.,1988, Potential for aquifer compaction, land subsidence, and earth fissures in the Tucson basin, Pima County, Arizona: U.S. Geological Survey Hydrologic Investigations Atlas HA-713, 3 sheets, scale 1:250,000.

Anderson, T.W., Freethey, G.W., and Tucci, Patrick, 1992 , Geohydrology and water resources of alluvial basins in south-central Arizona and parts of adjacent states: U.S. Geological Survey Professional Paper 1406-B, 67 p.

Bailey, M. A., 2002, Analysis of vertical hydraulic conductivity using heat as a tracer to estimate streambed infiltration in Rillito Creek, Tucson: University of Arizona, master's thesis, $158 \mathrm{p}$.

Blasch, K.W., Ferré, T.P., Hoffmann, J.P., Cordova, J.T., 2003, Field measured infiltration fluxes at the onset of ephemeral streamflow, EOS Transactions American Geophysical Union, v. 82, no. 47. p. F674.

Burkham, D.E., 1970, Depletion of streamflow by infiltration in the main channels of the Tucson basin, southeastern Arizona: U.S. Geological Survey Water-Supply Paper 1939-B, 36 p.

Clark, I.D. and Fritz, Peter, 1997, Environmental isotopes in hydrogeology: Boca Raton, Florida, CRC Press LLC, 328 p.

Craig, Harmon, 1961, Isotopic variations in meteoric waters: Science, v. 133, p. 1702-1703.

Constantz, J.E., Tyler, S.W., and Kwicklis, Ed, 2003, Temperature-profile methods for estimating percolation rates in arid environments: Vadose Zone Journal, v. 2, p. 12-24.

Davidson, E.S., 1973, Geohydrology and water resources of the Tucson basin, Arizona: U.S. Geological Survey WaterSupply Paper 1939-E, 81 p.

Driscoll, F.G., 1986, Groundwater and wells, $2^{\text {nd }}$ ed.: St. Paul, Minnesota, Johnson Division, 1108 p.

Epstein, Samual, and Mayeda, T.K., 1953, Variations of ${ }^{18} \mathrm{O}$ content of waters from natural sources: Geochimica et Cosmochimica Acta, v. 4, no. 5, p. 213-224.

Freeze, R.A., and Cherry, J.A., 1979, Groundwater: Englewood Cliffs, New Jersey, Prentice-Hall, Inc., 604 p.
Hammermeister, D.P., Blout, D.O., and McDaniel, J.C., 1986, Drilling and coring methods that minimize the disturbance of cuttings, core, and rock formations in the unsaturated zone, Yucca Mountain, Nevada, in Klute, A.L., ed., Proceedings of the National Water Well Association Conference on Characterization and Monitoring of the Vadose (Unsaturated) Zone, Worthington, Ohio, National Water Well Association, USA, p. 507-541.

Hanson, R.T., and Benedict, J.F., 1994, Simulation of groundwater flow and potential for land subsidence, Upper Santa Cruz Basin, Arizona: U.S. Geological Survey WaterResources Investigations Report 93-4196, 47 p.

Healy, R.W., and Ronan, A.D., 1996, Documentation of computer program VS2DH for simulation of energy transport in variably saturated porous media-modification of USGS computer program VS2DT: U.S. Geological Survey WaterResources Investigations Report 96-4230, 36 p.

Hoffmann, J.P., Ripich, M.A., and Ellett, K.M., 2002, Characteristics of shallow deposits beneath Rillito Creek, Pima County, Arizona: U.S. geological Survey Water-Resources Investigations Report 01-4257, 51 p.

Katz, L.T., 1987, Steady state infiltration processes along the Santa Cruz and Rillito Rivers, Ph.D. dissertation, Tucson, University of Arizona, $119 \mathrm{p}$.

Matlock, W.G., 1965, The effect of silt-laden water on infiltration in alluvial channels, Ph.D. dissertation, Tucson, University of Arizona, 109 p.

Moench, A.F. and Kisiel, C.C., 1970, Application of the convolution relation to estimating recharge from an ephemeral stream: Water Resources Research, v. 6, no. 4, p. 1087-1094.

Pool, D.R., 1985, Aquifer geology of alluvial basins of Arizona, in. Anderson T.W., and Johnson A.I., eds., Regional Aquifer Systems of the United States, Southwest Alluvial Basins of Arizona: American Water Resources Associations Monograph 7, p. 25-36

Pool, D.R., and Schmidt, Werner, 1997, Measurement of ground-water storage change and specific yield using the temporal-gravity method near Rillito Creek, Tucson, Arizona: U.S. Geological Survey Water-Resources Investigations Report 97-4125, 30 p.

Revesz, Kinga, and Woods, P.H., 1990, A method to extract soil water for stable isotopic analysis: Journal of Hydrology, v. 115 , p. $397-406$.

Schwalen, H.C., and Shaw, R.J., 1957, Ground water supplies of Santa Cruz Valley of southern Arizona between Rillito Station and the international boundary: Tucson, University of Arizona, Agricultural Experiment Station Bulletin 288, 119 p. 
Scott, R.L., Shuttleworth, W.J., Keefer T.O., and Warrick, A.W., 2000, Modeling multiyear observations of soil moisture recharge in the semiarid American Southwest: Water Resources Research, v. 36, no. 8, p. 2233-2247.

Smith, G.E.P., 1910, Groundwater supply and irrigation in the Rillito Valley: Tucson, University of Arizona, Agricultural Experiment Station Technical Bulletin 64, 244 p.

Tadayon, Saeid, Duet, N.R., Fisk, G.G., McCormack, H.F., Partin, C.K., and Rigas, P.D., 2000, Water resources dataArizona, water year 1999, U.S. Geological Survey WaterData Report, AZ-99-1, 370 p.

Talwani, Manik, Worzel, J.L., and Landisman, Mark, 1959, Rapid gravity computations for two-dimensional bodies with application to the Mendocino submarine fracture zone: Journal of Geophysical Research, v. 64, no. 1, p. 49-59.

Thatcher, L.L., Janzer, V.J., and Edwards, K.W., 1977, Methods for determination of radioactive substances in water and fluvial sediments: U.S. Geological Survey Techniques of Water-Resources Investigations, Chapter A-5, 95 p.

Tucson Water, 2000, Annual static water level basic data report Tucson basin and Avra Valley Pima County, Arizona, 1997: City of Tucson, Tucson Water, Planning and Engineering Division.
Wallace, D.E., and Lane, L.J., 1978, Geomorphic features affecting transmission loss potential on semiarid watersheds, in Hydrology and Water Resources in Arizona and the Southwest-Proceedings of the 1978 Meetings of the Arizona Section, American Water Resources Association and the Hydrology Section, Arizona Academy of Science, April 14-15, 1978, Flagstaff, Arizona: American Water Resources Association, v. 8, p. 157-164.

Water Resources Research Center, 1999, Water in the Tucson area-Seeking sustainability: College of Agriculture, University of Arizona, Tucson, Arizona, 155 p.

Webb R.H., and Betancourt, J.L., 1992, Climatic variability and flood frequency of the Santa Cruz River, Pima County, Arizona: U.S. Geological Survey Water-Supply Paper 2379, $40 \mathrm{p}$.

Won, I.J. and Bevis, M., 1987, Computing the gravitational and magnetic anomalies due to a polygon: Algorithms and Fortran subroutines, Geophysics, v. 52, p. 232-238.

Yitayew, Muluneh, 1990, Reference evapotranspiration estimates for Arizona: Tucson, University of Arizona, College of Agriculture, Agricultural Experiment Station Technical Bulletin 266. 